\title{
Bidirectional Synaptic Transmission in Necturus Taste Buds
}

\author{
Douglas A. Ewald and Stephen D. Roper \\ Department of Anatomy and Neurobiology, Colorado State University, Fort Collins, Colorado 80523 and the Rocky \\ Mountain Taste and Smell Center, University of Colorado Health Sciences Center, Denver, Colorado 80262
}

Pairs of taste cells were impaled with intracellular recording microelectrodes in intact taste buds in slices of Necturus lingual epithelium. Applying short pulses of $140 \mathrm{mM} \mathrm{KCl}$ or $200 \mathrm{mM} \mathrm{CaCl}_{2}$ solutions to the apical pore elicited receptor potentials in taste receptor cells. Chemostimulation of receptor cells elicited postsynaptic responses in basal cells in the taste bud. Postsynaptic responses in basal cells had a threshold for activation and did not saturate with increasing doses of chemical stimulus applied to the receptor cells. We directly depolarized individual receptor cells and tested whether this would evoke postsynaptic responses in basal cells. Depolarizing receptor cells to $\sim 0 \mathrm{mV}$ evoked small depolarizing responses in basal cells in $16 \%$ of the experiments. The properties of these responses were consistent with their being mediated by a chemical synapse. A comparison of the responses in basal cells evoked by depolarizing single receptor cells, with responses evoked by stimulating the entire receptor cell population with $\mathrm{KCl}$ suggests that there is extensive synaptic convergence from receptor cells onto each basal cell. We also tested whether electrical excitation of basal cells would elicit (retrograde) synaptic responses in receptor cells. Single depolarizing pulses (up to 1 sec duration) applied to basal cells through the intracellular recording microelectrode never evoked synaptic responses in receptor cells. However, when repetitive electrical stimuli were applied to basal cells (four to six $1 \mathrm{sec}$ depolarizations to $\sim 0 \mathrm{mV}$ every $12 \mathrm{sec}$ ) we observed prolonged effects on receptor cells in 11 of 23 experiments. These effects included an increase in the amplitude of receptor potentials elicited by $\mathrm{KCl}$ (mean $\pm \mathrm{SD}=+19 \pm 5 \%$ ), an increase in membrane input resistance of receptor cells $(+27 \pm 11 \%)$, and a hyperpolarization of receptor cells (3$10 \mathrm{mV}$ ). In control experiments, repetitive stimulation of one receptor cell never elicited such effects in another receptor cell. We investigated the possibility that serotonin (5-HT), released from basal cells, mediated the above modulatory effects on receptor cells. Bath-applied 5-HT $(100 \mu \mathrm{M}) \mathrm{mim}-$ icked the effects produced by repetitive basal cell stimulation (KCl responses increased by $23 \pm 12 \%$; input resistance increased by $24 \pm 11 \%$; hyperpolarization of 5-15 $\mathrm{mV} ; \mathrm{N}=14$ ). We conclude that basal cells release $5-\mathrm{HT}$ onto

\footnotetext{
Received June 23, 1993; revised Nov. 19, 1993; accepted Dec. 16, 1993.

We thank Drs. Albertino Bigiani, Rona Delay, Timothy Gilbertson, and Sue Kinnamon for critically reviewing the manuscript. This work was supported by NIH DC01238.

Correspondence should be addressed to Douglas A. Ewald, Department of Anatomy and Neurobiology, Colorado State University, Fort Collins, CO 80523.

Copyright (C) 1994 Society for Neuroscience 0270-6474/94/143791-14\$05.00/0
}

adjacent taste receptor cells and that this enhances the electrotonic propagation of receptor potentials from the apical (chemosensitive) tip to the basal (synaptic) processes of receptor cells. The net effect is that activation of basal cells effectively increases the chemosensitivity of taste receptor cells.

[Key words: Necturus, chemosensitivity, intracellular recording, taste bud, synapse, 5-HT]

Vertebrate taste buds contain cell types that are defined by their light and electron microscopic properties (reviewed by Kinnamon, 1987; Roper, 1989; Reutter and Witt, 1993). In Necturus taste buds, $90 \%$ of cells in each taste bud are thought to be receptor cells. These cells possess thin apical processes that terminate in specialized chemosensory membrane at the apical pore (reviewed by Kinnamon, 1988; Roper, 1989). The remaining $10 \%$ are basal cells that lack apical processes. An extensive network of chemical synaptic interactions has been morphologically identified in Necturus taste buds (Delay and Roper, 1988). Only a minority of the synapses are found between receptor cells and afferent nerve fibers. Instead, more than half of the synapses in the taste bud involve one type of basal cell, the "Merkel-like" basal cell (Delay and Roper, 1988; Delay et al., 1993). Merkel-like basal cells form synapses with afferent nerve fibers and with receptor cells. These studies have also shown chemical synapses in the reverse direction, that is, from basal cells onto receptor cells. In some cases, clusters of vesicles are found on both sides of pre- and postsynaptic membrane densities, suggesting the presence of bidirectional synapses (Delay and Roper, 1988). Bidirectional synapses have been investigated in invertebrates (Anderson, 1985) and are also thought to occur in the mammalian brain (Horvath et al., 1989). Synapses have also been observed between basal cells and afferent nerve fibers. The existence of two parallel targets for synaptic output from basal cells suggests multiple functions for basal cells. First, the hasal cell may play some role as part of a feedback circuit onto receptor cells. Second, the basal cell may function as an interneuron to transmit integrated input from receptor cells to the afferent nerve (Reutter, 1978; Reutter and Witt, 1993). Thus, morphological studies suggest that some degree of signal processing occurs in peripheral laste organs. That is, the chemosensitivity of taste buds may be modulated by synaptic events occurring between taste cells even prior to activation of sensory afferent fibers (Roper, 1992, 1993; Roper and Ewald, 1992).

Serotonin $(5-\mathrm{HT})$ is known to modulate the function of peripheral sensory organs in invertebrate systems (reviewed in Pasztor, 1989). 5-HT modulates mechanoreceptor function in the crustacean muscle (Pasztor and Bush, 1987; el Manira et al., 1991). In Aplysia sensory neurons, 5-HT enhances excit- 


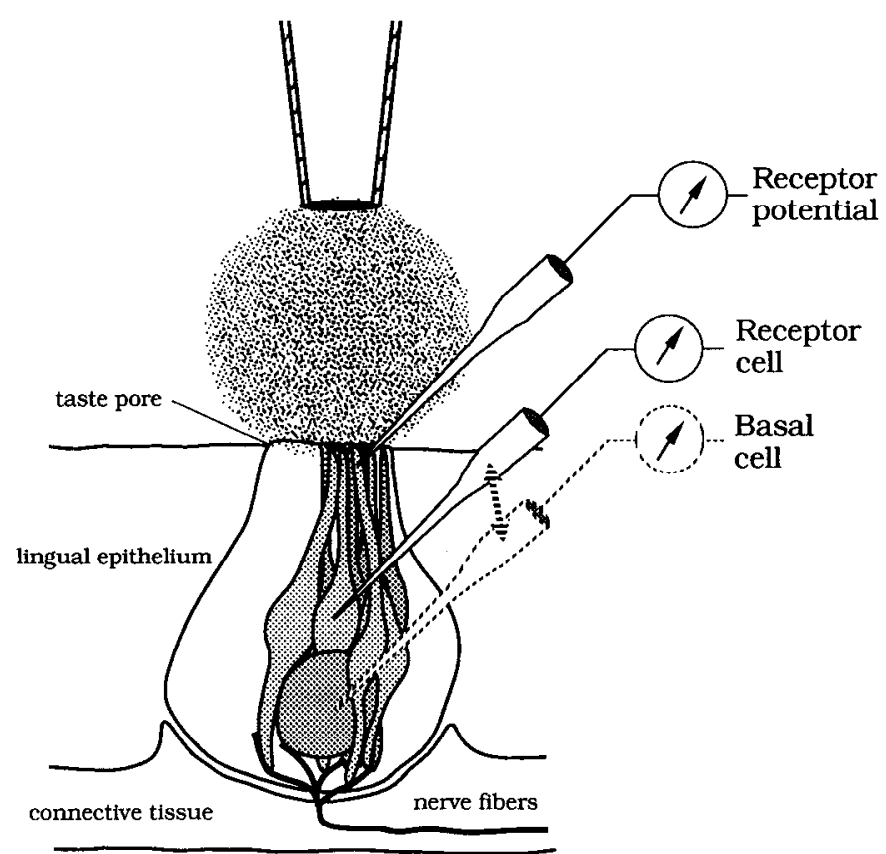

Figure 1. Schematic diagram of a Necturus taste bud in a slice of lingual epithelium showing locations of the pipette for focal chemical stimulation of the apical pore and the microelectrodes for intracellular recording. The taste bud is $\sim 100 \mu \mathrm{m}$ in length and diameter. Receptor cells extend from the apical pore to the base of the taste bud. A basal cell is shown in the basal region. For chemical stimulation, the apical ends of all the receptor cells were depolarized with brief pulses of 140 mм KCl or $200 \mathrm{~mm} \mathrm{CaCl}_{2}$ solution (see Materials and Methods). The stimulating pipette was positioned so that the edge of the spherical bolus of $\mathrm{KCl}$ or $\mathrm{CaCl}_{2}$ solution reached only the apical ends of the taste buds. Two microelectrodes were used to record receptor potentials in the apical end of the taste bud simultaneously with responses from a receptor cell or a basal cell in the basal region. Responses were identified as electrotonically conducted receptor potentials in the basal process of receptor cells, or postsynaptic responses in basal cells by measuring the latency of the responses (see text and Ewald and Roper, 1992).

ability by closing specific 5 -HT-sensitive K channels (Siegelbaum et al., 1982). In vertebrates, there is evidence that 5-HT can function as a neurotransmitter in sensory organs. For example, certain cell types in the retina have uptake systems specific for 5-HT (Osborne, 1982; Osborne et al., 1982; Mitchell and Redburn, 1985; Zhu et al., 1992), and 5-HT can modify the electrophysiological responses of ganglion cells to light (Thier and Wassle, 1984). Also in vertebrates, 5-HT has been shown to modulate peripheral nociceptive and mechanosensory receptors (Birrell et al., 1990; Lang et al., 1990; Taiwo and Levine, 1992; Todorovic and Anderson, 1992).

Evidence from morphological studies has long suggested the possibility that 5-HT may also be involved in the peripheral sensory organ of taste-the taste bud. 5-HT has been found in the taste buds of amphibians (Solovieva et al., 1978; Esakov et al., 1983), fish (Reutter, 1978), and mammals (Nada and Hirata, 1975; Fujimoto et al., 1987), but its function there has not yet been explored. In Necturus taste buds, one type of basal taste cell, the Merkel-like basal cell, contains 5-HT (Welton et al., 1992; Delay et al., 1993). This raises the possibility that Necturus taste buds may be well suited to investigate whether Merkellike basal cells release 5-HT to modulate taste bud function.

In our previous work we have shown that stimulating the taste bud with potassium and calcium salts elicits postsynaptic responses in basal cells (Ewald and Roper, 1992). Thesc experiments were conducted by impaling taste cells with a single microelectrode and recording sequentially from a series of receptor and basal cells. In the present experiments we have used two microelectrodes to record simultaneously from a receptor cell and a basal cell during chemical stimulation. With this new approach we have been able to study synaptic transmission between receptor and basal cells, and to observe responses in basal cells produced by direct electrical depolarization of single receptor cells. Our data suggest that there is extensive excitatory synaptic convergence from many receptor cells to only a few basal cells. Further, the findings suggest that basal cells, in addition to receiving synaptic input from receptor cells, modulate chemosensory responses in taste buds by releasing 5 - $\mathrm{HT}$ onto adjacent receptor cells.

\section{Materials and Methods}

Intracellular recordings were made from cells in taste buds in a preparation of $250-\mu \mathrm{m}$-thick transverse sections of Necturus lingual epithelium, as previously described (Ewald and Roper, 1992; Bigiani and Roper, 1993). However, instead of using a single microelectrode as in prior studies, two microelectrodes were used to record simultaneously from pairs of taste cells in the present experiments.

Animals and tissue preparation. Necturus maculosus, obtained from Kan's Scientific (Germantown, WI) or Graska Biological (Oshkosh, WI), were maintained in 150 gallon aquaria at $10^{\circ} \mathrm{C}$ and fed minnows, ad libitum. Animals were anesthetized in ice water for $20 \mathrm{~min}$ before killing. After an animal was decapitated and pithed, its tongue was removed and the epithelial layer plus the underlying basal lamina was dissected from the rest of the tongue. Slices of lingual epithelium were prepared by attaching the dissected epithelial layer onto a cross section of carrot with cyanoacrylate glue and cutting $250 \mu \mathrm{m}$ transverse slices with a vibrating razor blade mounted on a micromanipulator. Slices containing taste buds were mounted in a shallow perfusion chamber for intracellular recording. At all stages of these procedures, tissues were kept bathed with ice-cooled amphibian physiological saline (APS) as follows (in mM): $112 \mathrm{NaCl}, 2 \mathrm{KCl}, 8 \mathrm{CaCl}_{2}$, and $5 \mathrm{HEPES}, \mathrm{pH}$ 7.2. Slices prepared in this manner were viable for several hours, and responses from taste cells could be recorded for this duration. Recordings were made at room temperature.

Chemostimulation. A glass capillary pipette (tip diameter $=20 \mu \mathrm{m}$ ) filled with $140 \mathrm{mM} \mathrm{KCl}$ or with $200 \mathrm{mM} \mathrm{CaCl}_{2}$ was connected to a Picospritzer and positioned $\sim 100 \mu \mathrm{m}$ from the apical end of the taste bud (Fig. 1). A second capillary suction pipette (tip diameter $=200 \mu \mathrm{m}$ ) was mounted on the same micromanipulator with its tip $0.5 \mathrm{~mm}$ behind the tip of the stimulus delivery pipette; this second pipette provided a constant suction to withdraw solution from the immediate vicinity of the epithelial surface. Doses of $140 \mathrm{~mm} \mathrm{KCl}$ or $200 \mathrm{~mm} \mathrm{CaCl}_{2}$ of short duration (200-800 msec) were applied to the taste pore at low pressure (1.5-3 psi). With the above arrangement of stimulus and suction pipettes, the chemical stimulus formed a compact sphere of $\sim 100 \mu \mathrm{m}$ (monitored with fast green dye in the pipette) that was rapidly removed at the end of each stimulus pulse. Fast green dye by itself had no effect on taste cells. This arrangement of stimulus delivery and focal suction pipettes produced a "quasi-laminar," spherical bolus of chemostimulant that could be focused onto the apical, chemosensitive tips of the taste receptor cells with minimal diffusion to basolateral regions of the taste bud (cf. Ewald and Roper, 1992).

Recording. Recording electrodes were pulled on a Brown-Flaming microelectrode puller (Sutter Instrument Co., Novato, CA) and filled with $2.5 \mathrm{M} \mathrm{KCl}$ (resistances of 20-50 M $\Omega$ ). Two taste cells were impaled with microelectrodes to record simultaneously receptor potentials in the apical end of the taste bud and responses from either a basal cell or the basal process of a receptor cell (Fig. 1). Responses were identified on the basis of their latencies either as receptor potentials conducted electrotonically to the basal process of a receptor cell, or as postsynaptic responses in a basal cell (cf. Ewald and Roper, 1992). We determined the latency of the responses (recorded in the basal region of the taste bud) by comparing their onsets with the onsets of receptor potentials recorded in the apical region of the taste bud. Our previous study (Ewald and Roper, 1992), utilizing dye-filled microelectrodes to identify cell 
types, showed that response latencies $>75 \mathrm{msec}$ were consistent and reliable indications that the microelectrode was inserted in a basal cell.

\section{Results}

In our previous work (Ewald and Roper, 1992), we found that chemical stimulation of the apical tips of Necturus taste cells elicited receptor potentials in receptor cells and postsynaptic responses in basal cells. Basal cell responses were distinguished from receptor cell responses by their smaller amplitude and long latencies (>75 msec). In the present experiments two microelectrodes were used to record simultaneously from pairs of taste cells during chemical stimulation in the lingual slice preparation, as shown schematically in Figure 1.

Figure 2 shows receptor potentials and postsynaptic basal cell responses recorded simultaneously in response to a pulse of $\mathrm{KCl}$ applied to the taste pore. $\mathrm{KCl}$ is an effective chemosensory depolarizing stimulus for all taste receptor cells in Necturus (Kinnamon and Roper, 1988b; Bigiani and Roper, 1991) and acts on the high density of $\mathrm{K}$ channels that is present on the apical membrane (Kinnamon et al., 1988; McBride and Roper, 1989). Figure $2 A$ shows the typical latency for a basal cell response compared to the simultaneously recorded receptor potential. Using Lucifer yellow injection to identify cells, responses with latencies $>75 \mathrm{msec}$ were found exclusively from basal cells (Ewald and Roper, 1992). Receptor potentials evoked by $\mathrm{KCl}$ were associated with a decrease in input resistance of the receptor cell (mean $\pm \mathrm{SD}=-34 \pm 21 \%, N=10$ ), as shown in the top trace of Figure $2 B$ (cf. Bigiani and Roper, 1991). This was also the case for postsynaptic responses recordcd in basal cells as shown in the bottom trace of Figure $2 B(-14 \pm 10 \%$, $N=10$ ).

Figure 3 shows responses in receptor cells and concurrent postsynaptic responses in basal cells, elicited by a different chemical stimulus, $\mathrm{CaCl}_{2}(200 \mathrm{~mm})$. As shown by Bigiani and Roper (1991), $\mathrm{Ca}^{2+}$ salts elicit a receptor potential by a fundamentally different mechanism than $\mathrm{KCl} . \mathrm{Ca}^{2+}$ reduces the apical $\mathrm{K}$ conductance and consequently depolarizes receptor cclls while increasing the cell input resistance (mean $\pm \mathrm{SD}=$ $+66 \pm 43 \%, N=7$ ), as is shown in Figure 3 (upper traces). The consequence of this is that $\mathrm{CaCl}_{2}$ responses have a maximum amplitude, and thus saturate, only $10-30 \mathrm{mV}$ above resting potential. As is shown in Figure 3 (lower traces), basal cell postsynaptic potentials elicited by $\mathrm{CaCl}_{2}$ typically were much smaller than those evoked by $\mathrm{KCl}$ and consistently had latencies longer than those elicited by $\mathrm{KCl}$ (compare Figs. 2, 3). Corrcsponding to the smaller $\mathrm{CaCl}_{2}$ responses, there were smaller (or sometimes at the level of noise, and thus indistinguishable) decreases in input resistance associated with the postsynaptic responses $(-9 \pm 6 \%, N=7)$. Thus, despite the fundamentally different mechanisms for generating receptor potentials $\left(\mathrm{CaCl}_{2}\right.$ vs $\mathrm{KCl}$ and decreased vs increased membrane conductance), the postsynaptic responses were still accompanied by increases in membrane conductance. This makes it unlikely that the basal cell responses merely represented uncontrolled spread of the chemical stimulus to the bottom of the taste bud as was also shown in Ewald and Roper (1992).

In the following experiments we have investigated the input/ output properties of synaptic connections between receptor cells and basal cells. We systematically varied the amplitude of receptor potentials (by varying the duration of the $\mathrm{KCl}$ stimulus) and simultaneously recorded postsynaptic potentials in basal cells.

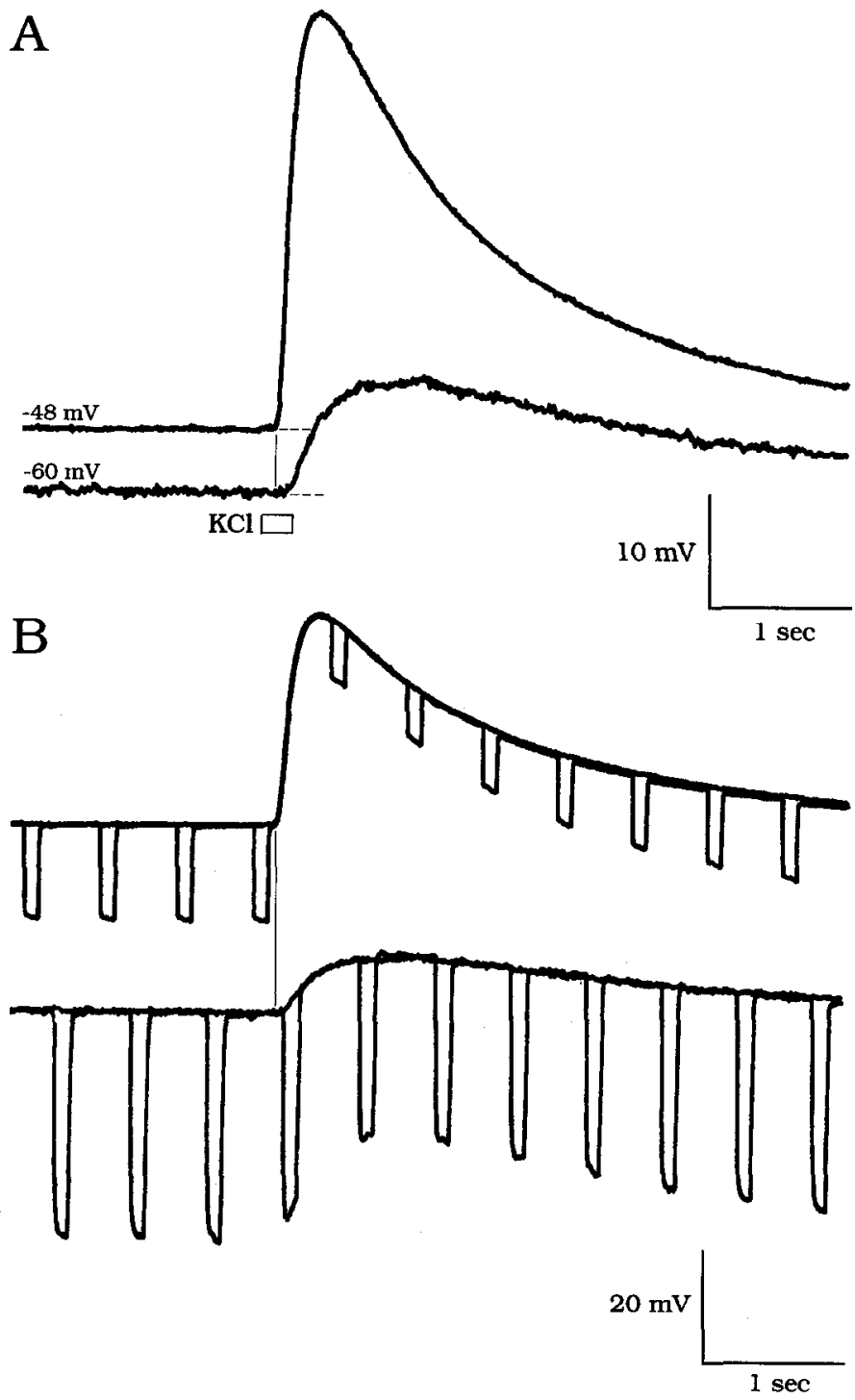

Figure 2. Receptor potential and basal cell response elicited by $\mathrm{KCl}$, recorded simultaneously from two cells in a Necturus taste bud. A: Upper trace, Receptor potential in taste receptor cell, elicited by a $200 \mathrm{msec}$ pulse of $140 \mathrm{mM} \mathrm{KCl}$ (open bar). This response was recorded in the apical end of the receptor cell. Lower trace, Simultaneously recorded response in a basal cell. Resting potentials are noted to the left of each trace. The latency of the basal cell response is $100 \mathrm{msec}$ after the onset of the receptor potential. This long latency is characteristic of basal cell responses (cf. Ewald and Roper, 1992). $B$, Input resistances were measured with $100 \mathrm{msec}$ hyperpolarizing pulses applied at $0.5 \mathrm{~Hz}$ through the balanced bridge circuit of the recording electrodes. Upper traces (superimposed), Receptor potentials (taste receptor cell) with and without hyperpolarizing pulses. Lower traces (superimposed), Basal cell responses with and without hyperpolarizing pulses. In these records, the input resistance of the receptor cell decreased $50 \%$ and the basal cell $20 \%$ during the responses.

Examples of receptor cell and basal cell responses to increasing doses of $\mathrm{KCl}$ are shown with concurrent apical receptor potentials in Figure $4 A$. The input/output relations for the two experiments are plotted in Figure $4 B$. By analyzing six pairs of dose-response relations such as these (three receptor and three basal cells with their paired apical receptor potentials), the following generalizations can be made. First, the amplitude of apically recorded receptor potentials saturates at about -10 to 


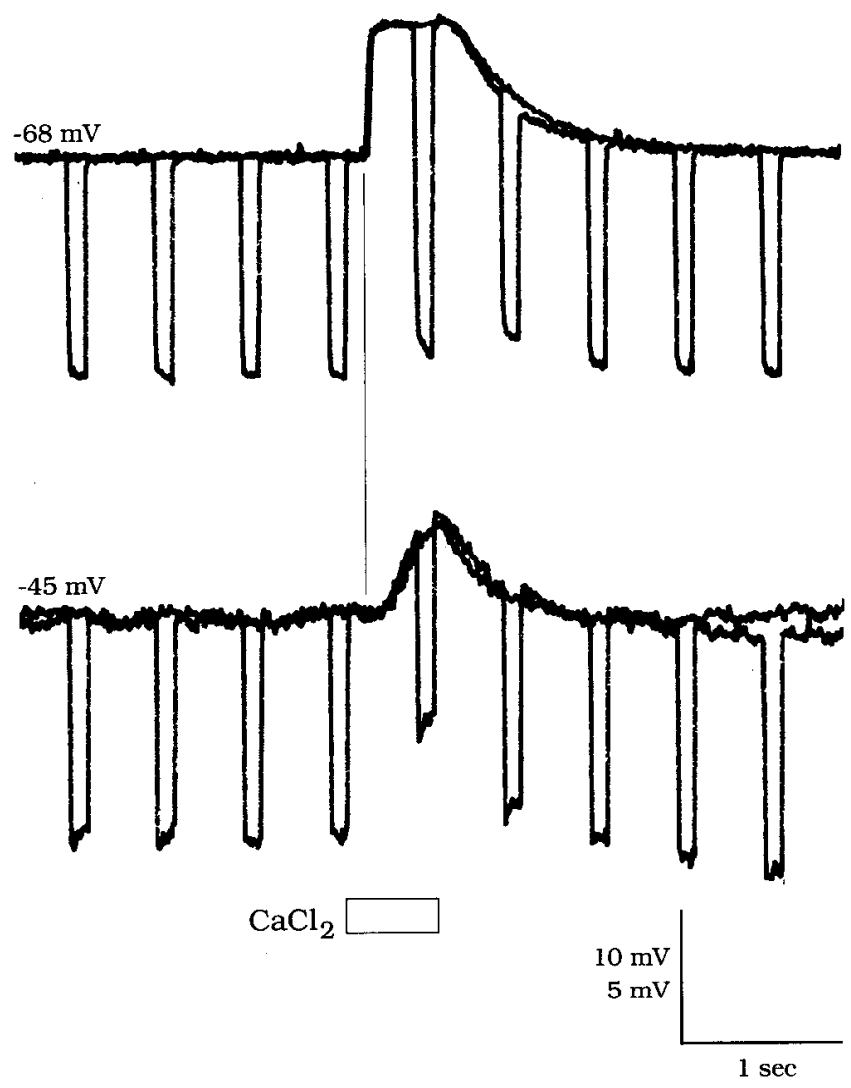

Figure 3. Receptor potential and basal cell response elicited by $\mathrm{CaCl}_{2}$, recorded simultaneously from two cells in a Necturus taste bud. Top traces (superimposed), Receptor potentials recorded in the apical end of a taste receptor cell, elicited by a $500 \mathrm{msec}$ pulse of $200 \mathrm{~mm} \mathrm{CaCl}$ (open bar) with and without hyperpolarizing pulses as in Figure $2 B$. Bottom traces (superimposed), Simultaneously recorded basal cell responses. Resting potentials are noted to the left of each trace. Compared to $\mathrm{KCl}$ stimulation, receptor potentials clicitcd by $\mathrm{CaCl}_{2}$ were consistently smaller. Thus, longer pulses of $\mathrm{CaCl}_{2}$ ( $>200 \mathrm{msec}$ duration) were required to elicit basal cell responses and the delays before onset of the basal cell responses were longer. Receptor potentials elicited by $\mathrm{CaCl}_{2}$ are associated with an increase in input resistance $(50 \%$ in this case) whereas basal cell responses are associated with a decrease $(12 \%$ in this case). $\mathrm{Ca}^{2+}$ causes closure of $\mathrm{K}$ channels (Bigiani and Roper, 1992).

$+10 \mathrm{mV}$ in response to increasing doses of $\mathrm{KCl}$. This is to be expected since the response is generated of the shift in the electrochemical equilibrium potential for $\mathrm{K}^{+}$(from $\sim-90 \mathrm{mV}$ to $+8-14 \mathrm{mV}$, for $\left[\mathrm{K}^{+}\right]_{o}=140 \mathrm{~mm}$ and assuming $\left[\mathrm{K}^{+}\right]_{i}=80-100$ ImM; Kimamon and Roper, 1987, 1988b) in combination with basolateral shunt conductances and electrogenic pumps, if any. Second, responses recorded in the basal processes of receptor cells also saturate, but at a much smaller amplitude. This is consistent with electrotonic conduction of the receptor potential from apical to basal end of the cell (Fig. 4B, left). Third, postsynaptic responses in basal cells do not saturate with increasing $\mathrm{KCl}$ doses (pulse durations up to $800 \mathrm{msec}$; Fig. $4 B$, right). The observation that the amplitudes of the postsynaptic responses are increasing when the presynaptic responses have already saturated at first appears contradictory. However, it is important to note that the durations of the presynaptic responses continue to increase with increasing $\mathrm{KCl}$ dose, even after their amplitudes have saturated.

Some variability occurs from experiment to experiment in the dose-response relationships due to slight changes in $\mathrm{KCl}$ application at the taste pore (pulse pressure, distance of the $\mathrm{KCl}$ pipette tip from apical pore, perfusion rate, etc.). Thus, a more accurate measure of synaptic transfer is to plot responses (recorded in the basal region) as a function of the apically recorded receptor potential (Fig. 5). The threshold for responses in the basal processes of receptor cells was near the resting potential (Fig. $5 A$, top), consistent with electrotonic propagation of these signals from the apical region where they were generated. In contrast, for each of the three basal cells the (apical) receptor potential had to exceed a threshold, ranging between 50 and 80 $\mathrm{mV}$, to elicit postsynaptic responses (Fig. $5 \mathrm{~A}$, bottom). These thresholds corresponded to a receptor cell membrane potential of $\sim-20 \mathrm{mV}$ since the three cells had different resting potentials. When the responses are plotted as a function of the percentage of the maximum receptor potential, which partially compensates for differences in resting potential, the thresholds are more similar (Fig. 5B). This threshold also depended on the duration of the presynaptic receptor potential. Thus, postsynaptic responses in basal cells could also be evoked by $\mathrm{CaCl}_{2}$, which produced prolonged presynaptic membrane potentials below $-20 \mathrm{mV}$ (see Fig. 3).

The preceding experiments, combined with our previous results (Ewald and Roper, 1992), suggest that synaptic connections between receptor cells and basal cells have many characteristics that are consistent with known properties of chemical synapses. Transmitter release is elicited when the presynaptic potential depolarizes to a sufficient amplitude to activate $\mathrm{Ca}$ channels. Once the presynaptic threshold has been exceeded, the postsynaptic potential is a function of both the level of presynaptic depolarization and the duration this depolarization is maintained. It must still be qualified, however, that this understanding of the voltage and time dependence of postsynaptic responses in basal cells is under conditions in which the entire receptor cell population is stimulated by $\mathrm{KCl}$. No firm conclusions can be made about the properties of individual synapses without knowing the number of synapses involved in producing a postsynaptic response in an individual basal cell. This is the topic of the following experiments.

We attempted to impale pairs of cells (receptor cell plus basal cell) that were synaptically coupled, and directly stimulate the presynaptic element (receptor cell). Figure $6 \mathrm{~A}$ shows a schematic diagram of the method used to stimulate individual receptor cells and record responses in basal cells. These experiments were complicated by the fact that the impalements must be made at random from a total population of approximately 90 receptor cells and 10 basal cells per taste bud (Delay and Roper, 1988), and that the dual impalements had to be maintained for a sufficient time to collect the relevant data. Nonetheless, we were able to detect postsynaptic responses elicited by direct stimulation of receptor cells in 14 of 88 such pairs of cells $(16 \%)$. Receptor cells were depolarized with 1 sec current pulses passed through the recording electrode. We observed no consistent responses in basal cells following briefer pulses injected into receptor cells.

In $16 \%$ of receptor cell/basal cell pairs, large depolarizing pulses (to $\sim 0 \mathrm{mV}$ ) applicd to the receptor cells evoked small depolarizing responses in basal cells. One example of such recordings is shown in Figure $6 B$. The top trace shows the $1 \mathrm{sec}$ depolarization of the receptor cell followed by a $\mathrm{KCl}$ response. The bottom trace shows the small depolarizing response elicited in a basal cell during the direct depolarization, followed by a larger response to the chemical stimulation. A hyperpolarizing 


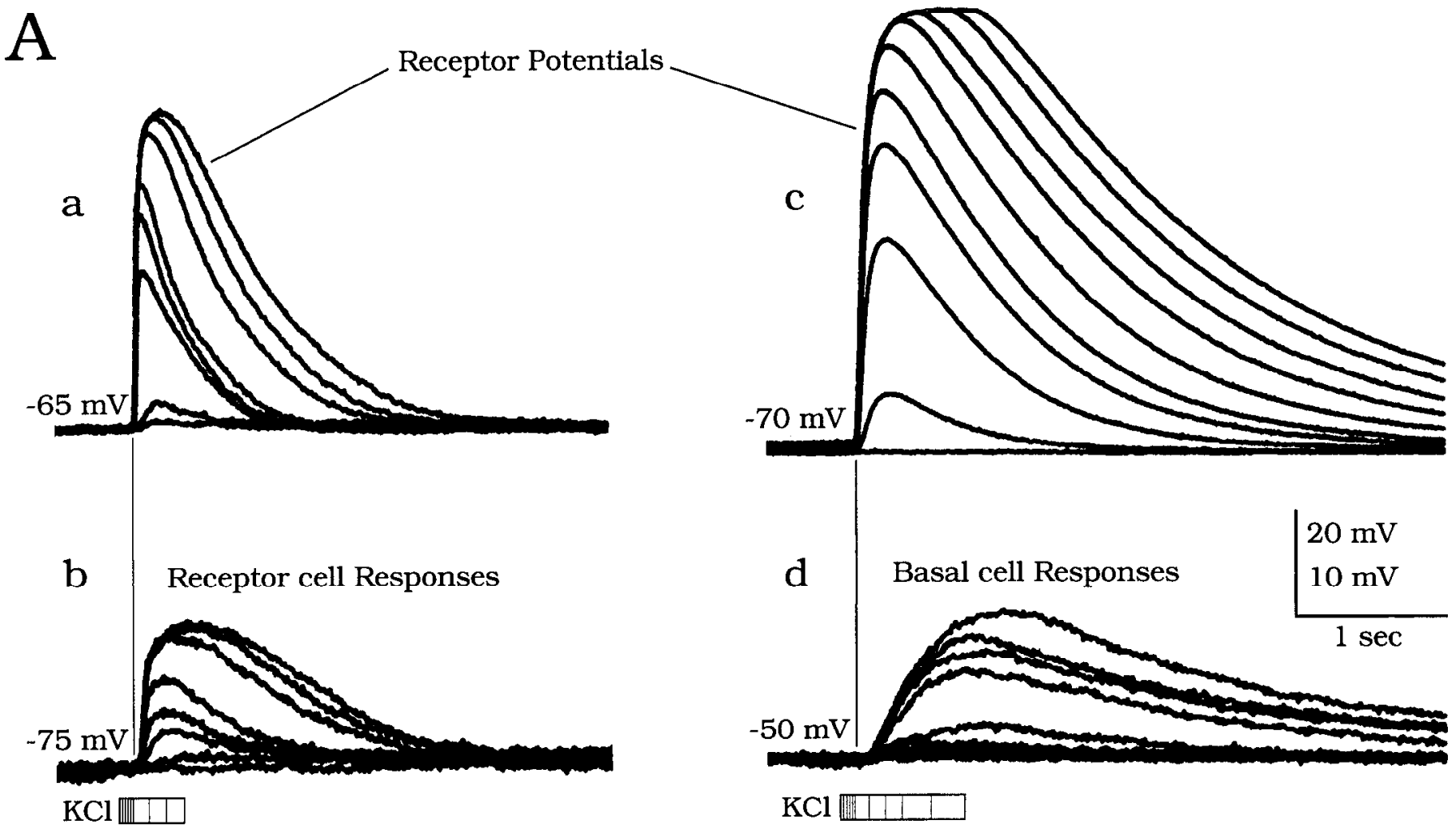

$\mathrm{B}$

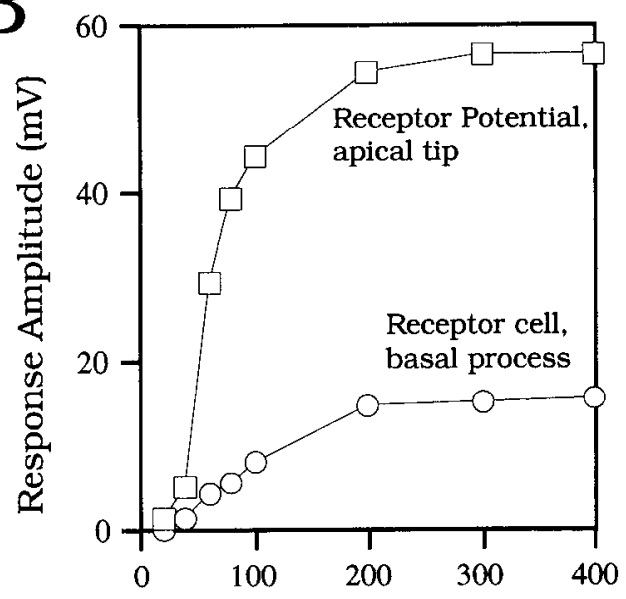

Pulse duration (msec)

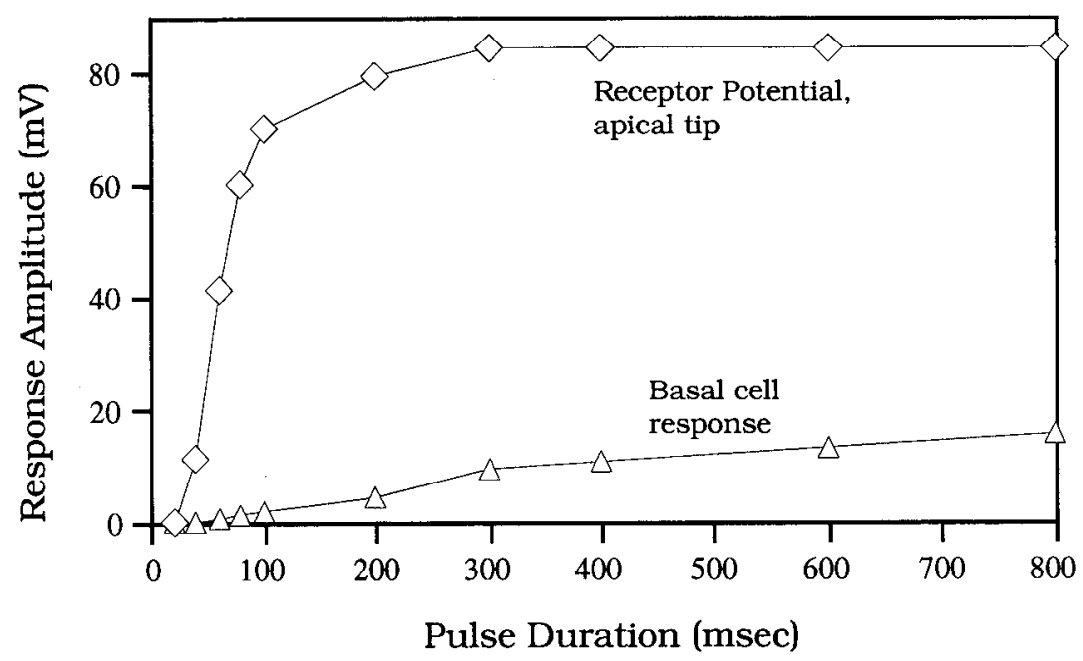

Figure 4. Relationships between receptor potentials (apical recording) and responses recorded in the basal region of taste buds. $A$, Data from two different pairs of recordings $(a, b$ and $c, d$ ). $a$ (superimposed traces), Receptor potentials recorded in the apical end of a taste receptor cell, elicited by increasing doses of $\mathrm{KCl}$ (pulse durations, $20-400 \mathrm{msec}$; bars below traces). $b$ (superimposed traces), Simultaneous recordings from the basal process of a receptor cell in the same taste bud. $c$, Receptor potentials in another taste bud, elicited by increasing doses of $\mathrm{KCl}$ (pulse durations, 20-800 msec). $d$, Simultaneously recorded basal cell responses. Receptor potential amplitudes increase with increasing $\mathrm{KCl}$ dose. At high $\mathrm{KCl}$ doses, the duration of the receptor potentials increased without a concomitant increase in amplitude (e.g., traces in c). The amplitude of receptor cell responses (recorded in its basal process; traces in $b$ ) was $\sim 30 \%$ of the apical receptor potential amplitudes. The amplitude of postsynaptic responses in basal cells (traces in d) was negligible for low doses of $\mathrm{KCl}$ (durations $<100 \mathrm{mscc}$ ) and incrcascd for $\mathrm{KCl}$ doses above $100 \mathrm{mscc}$. Resting potentials are noted to the left of each trace. $B$ : Left, Plots compare the $\mathrm{KCl}$ dose-response relations for receptor potentials $(\square)$ and responses in the basal process of a receptor cell $(O)$ for the pair of cells shown in $a$ and $b$. Right, Comparison of $\mathrm{KCl}$ dose-response relations for receptor potentials $(\hat{\theta})$ and postsynaptic potentials in a basal cell $(\Delta)$ for the pair of cells shown in $c$ and $d$.

pulse of comparable magnitude produced no discernable response eliminating the possibility that the basal cell response represented electrical coupling or artifactual field potentials. Electrical coupling has been observed between receptor cells in this and other species, using Lucifer yellow dye-filled microelec- trodes (Teeter, 1985; Yang and Roper, 1987; Sata and Sato, 1989). Electrical coupling has never been observed between receptor and basal cells, consistent with our recordings described here.

Two consistent features in the direct receptor-to-basal cell 


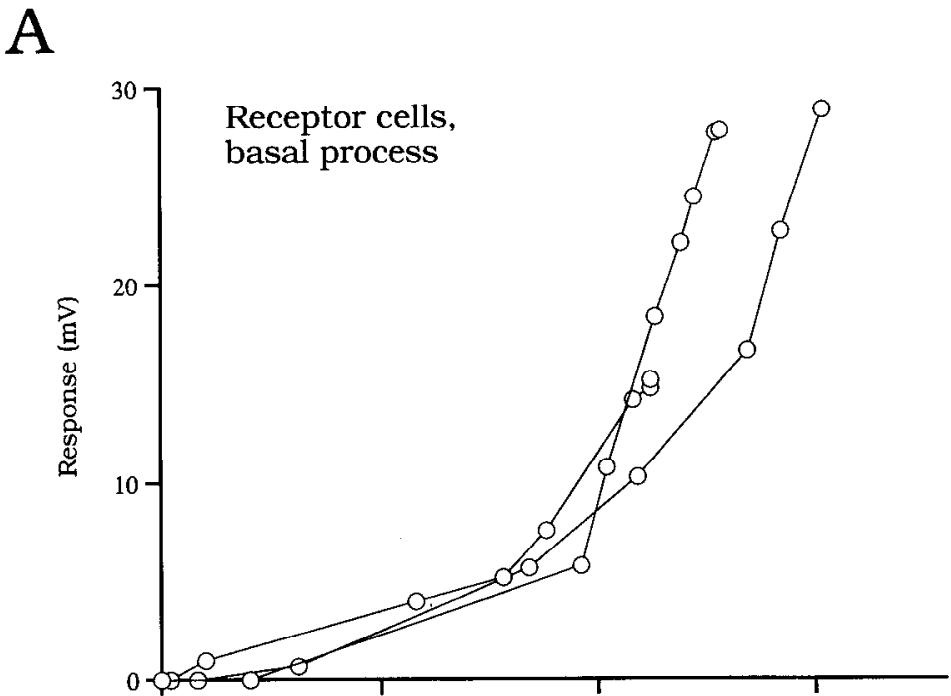

$\mathrm{B}$
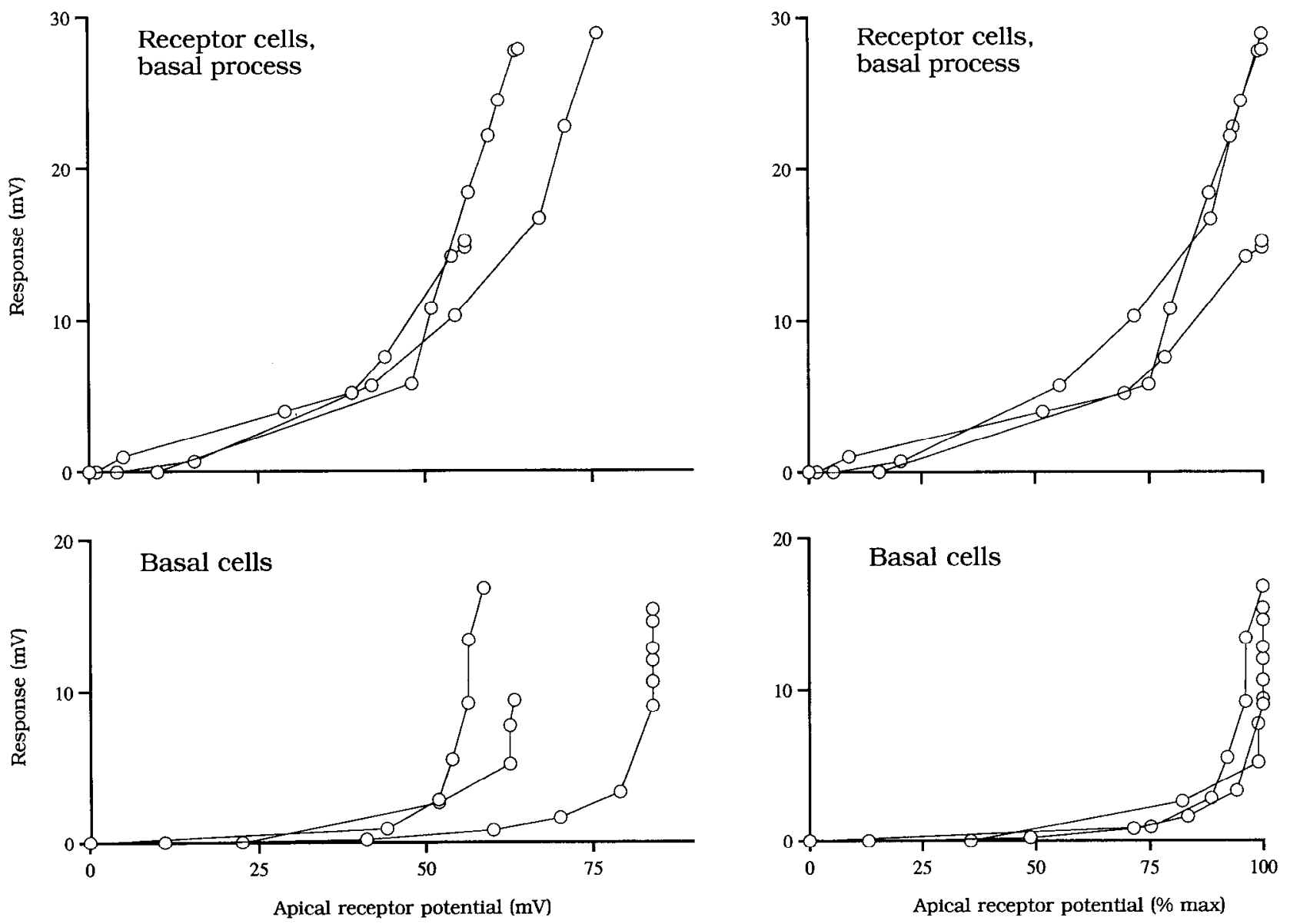

Figure 5. Dependence of receptor cell responses (recorded in the basal process) and postsynaptic basal cell responses on apical receptor potentials. $A$, Plots compare the input/output relations for responses from three receptor cells (top, impalement in basal process) and postsynaptic responses from three basal cells (bottom) as a function of the amplitude of receptor potentials ( $\mathrm{KCl}$ responses) concurrently recorded from the apical end of a receptor cell. Abscissa, amplitude of apical receptor potential; Ordinate, responses recorded in basal processes of receptor cells (top) or postsynaptic responses recorded in basal cells $($ hottom $)$. $B$. The same data are replotted as a function of the percentage maximum apical receptor potential.

responses were observed: (1) the onset of the responses coincided with the onset of the depolarizing pulses, and (2) the amplitude of the postsynaptic responses $(0.4 \pm 0.2 \mathrm{mV}, N=14)$ was about one-eighth that evoked by chemical stimulation of the entire population of receptor cells $(3.0 \pm 0.4 \mathrm{mV}, N=14)$. These results suggest that the long latency in postsynaptic responses, when they are evoked by chemostimulation, is due to the time required for the receptor ccll to reach a threshold level of depolarization. This was consistent with the finding that weaker and/or briefer depolarizations of the receptor cell often failed to elicit a detectable response in the basal cells. That is, there appeared to be a threshold. Due to the small amplitude of the postsynaptic basal cell responses, however, this was not investigated in detail.

Since ultrastructural studies suggest that there may be bidirectional synapses between receptor cells and basal cells, we tested whether there might also be direct synaptic transmission in the opposite direction, that is, from basal cells to receptor cells. We reversed the experimental paradigm described above and used electrical excitation of basal cells to test for synaptic responses in receptor cells (Fig. 7). Receptor cells were impaled in the basal region of taste buds so that the site of recording would be near any putative synaptic regions (Fig. 7).
Stimulating basal cells with single $1 \mathrm{sec}$ pulses (to $0 \mathrm{mV}$ ) never elicited responses in receptor cells $(N=20$ pairs of receptor/ basal cells). An example of one such experiment is shown in Figure 8. In this experiment, a small regenerative response occurred during the electrical depolarization of the basal cell (small shoulder marked with arrow). However, during these experiments we noticed that there was a tendency for repeated trials of stimulation to increase responses of taste cells to chemical stimulation. We postulated that although single depolarizing current pulses applied to basal cells did not elicit direct synaptic responses in receptor cells, multiple electrical stimulation might modulate receptor cell function over a longer time course. In the following experiments we systematically investigated this possibility.

We tested the effect of trains of direct electrical stimulation of basal cells on chemosensory responses, that is, $\mathrm{KCl}$ responses, of receptor cells and on passive membrane properties in 23 receptor/basal cell pairs. Basal cell stimulation consisted of four to six $1 \mathrm{sec}$ depolarizing pulses applied at $12 \mathrm{sec}$ intervals. We injected depolarizing currents of sufficient magnitude to depolarize the basal cells to $\sim 0 \mathrm{mV}$. We recorded the membrane potential, the input resistance, and the amplitude of $\mathrm{KCl}$ responses in the receptor cells for at least 1 min before and after 

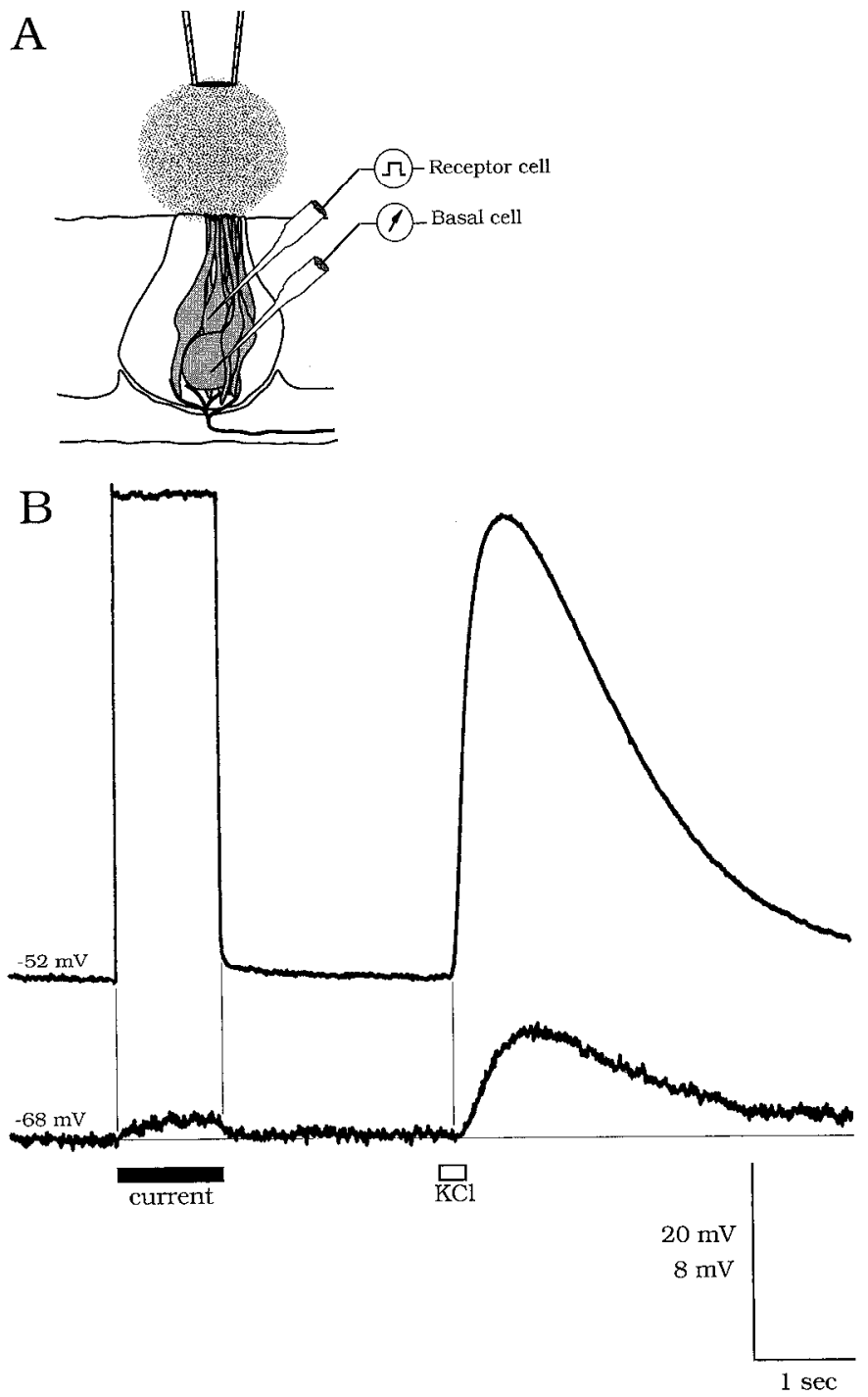

Figure 6. Direct electrical stimulation of receptor cells elicits small postsynaptic responses in basal cells. A, Schematic diagram of a taste bud in a slice preparation showing locations of the pipette for chemical stimulation and the microelectrodes for electrical stimulation (receptor cell) and intracellular recording (basal cell). $B$ : Top trace (receptor cell), Direct electrical depolarization (solid bar below traces) is followed by focal $\mathrm{KCl}$ stimulation (open bar below traces); $1 \mathrm{sec}$ depolarizing current pulses to $\sim 0 \mathrm{mV}$ were injected into the receptor cell. Iower trace (basal cell), Averaged responses (of four consecutive recordings) from an adjacent basal cell. Resting potentials are noted to the left of each trace.

stimulating basal cells with a train of pulses. Figure 9 shows the results from one experiment where five depolarizing pulses were applied to the basal cell. Even after the first stimulus, the $\mathrm{KCl}$ response in the receptor cell seemed to be somewhat enhanced, though this may have merely been within the range of response variability. However, $1 \mathrm{~min}$ after repetitively stimulating the basal cell, the amplitude of the $\mathrm{KCl}$ responses recorded in the receptor cell was consistently larger, $130 \%$ compared to before basal cell stimulation. Furthermore, the receptor cell input resistance was $140 \%$ of control values, and the receptor cell membrane potential was hyperpolarized $5 \mathrm{mV}$. These three effects, which we will refer to as "modulatory effects," were observed in 11 of 23 pairs of receptor/basal cells and consistently occurred in these cells following electrical stimulation of basal cells (i.e.,

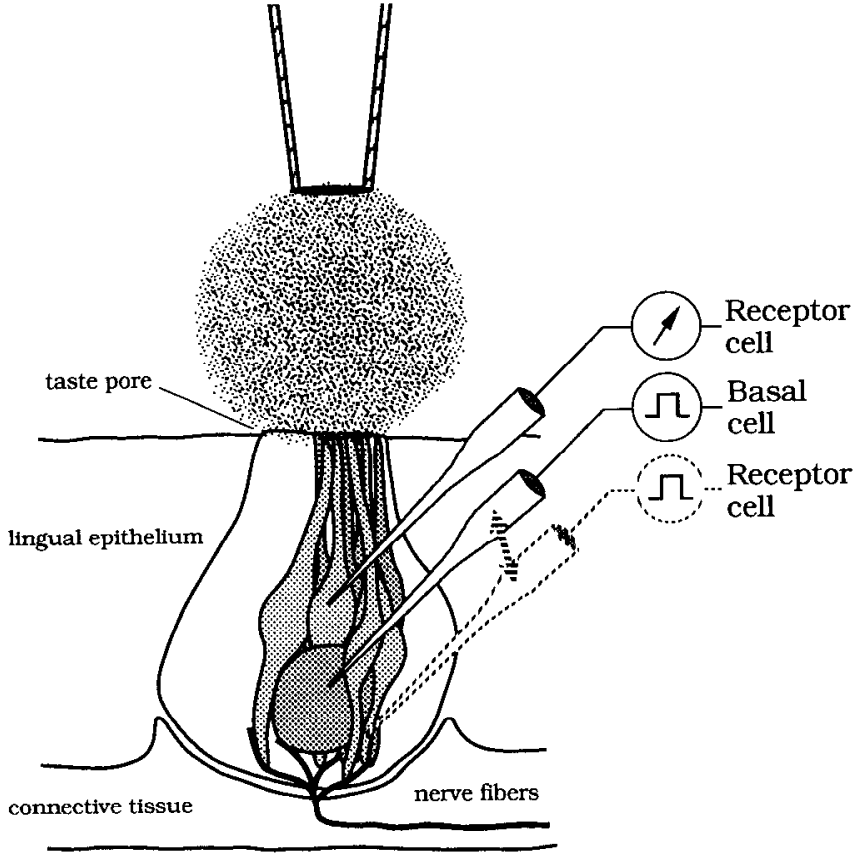

Figure 7. Schematic diagram of a taste bud in a slice preparation showing locations of the pipette for focal chemical stimulation of the apical pore and the microelectrodes for intracellular recording and for electrical stimulation.

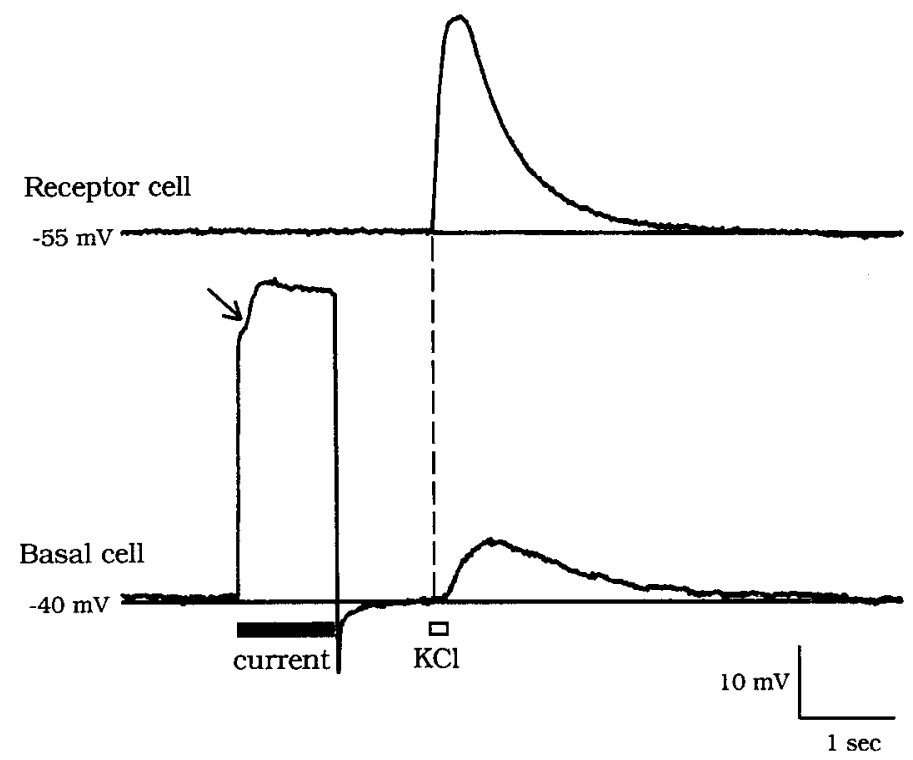

Figure 8. Direct electrical excitation of basal cells does not elicit postsynaptic responses in receptor cells when single pulses are applied. Upper trace, Intracellular recording from a receptor cell. Lower trace, Concurrent intracellular recording from an adjacent basal cell. A 1 sec depolarizing current pulse was injected into the basal cell (solid bar). One second following the current pulse, a $200 \mathrm{msec}$ pulse of $\mathrm{KCl}$ (open bar). was applied to the taste pore, as shown in Figure 1 . The current pulse produced a large depolarization in the basal cell, including a small regenerative response (arrow). However, postsynaptic responses were not observed in receptor cells during depolarizing pulses applied to basal cells. $\mathrm{KCl}$ evoked a large depolarizing receptor potential in the receptor cell (top trace) and a smaller postsynaptic response with delayed onset in the basal cell (bottom trace; compare Fig. 2). Resting potentials are given to the left of each trace. 
A
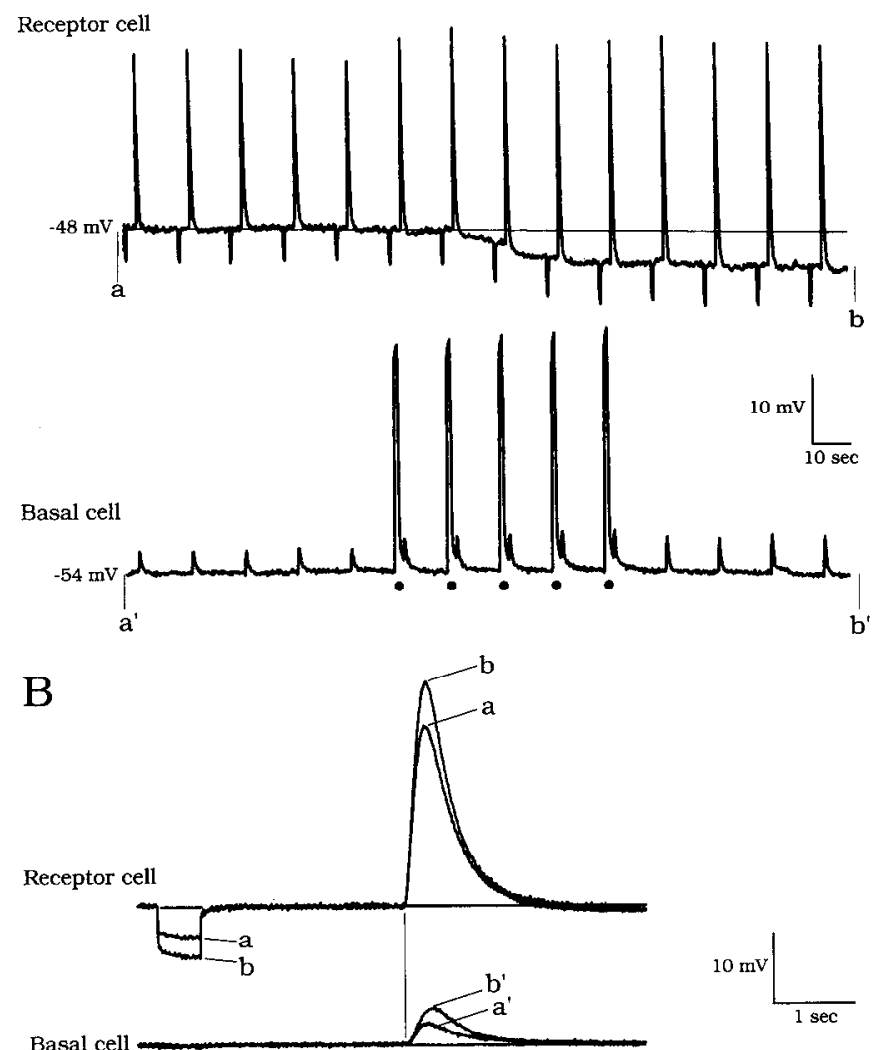

Figure 9. Repetitive stimulation of basal cells produces responses in adjacent receptor cells. A: Upper trace, A continuous 3 min intracellular recording from a taste receptor cell. The microelectrode was inserted into the basal process of the receptor cell. Focal $\mathrm{KCl}$ stimulation applied to the apical tip (taste pore) elicited receptor cell potentials, $20-40 \mathrm{mV}$, every $12 \mathrm{sec} . \mathrm{KCl}$ responses were alternated with brief hyperpolarizing constant current pulses (not shown) to test the input resistance (downward deflections, $\sim 5 \mathrm{mV}$ ). Lower trace, Concurrent intracellular recording from an adjacent basal cell. Small depolarizing responses represent the postsynaptic potentials generated by receptor potentials in basal cells (see text). Five depolarizing current pulses, of $1 \mathrm{sec}$ duration, (๑) were injected halfway through the $3 \mathrm{~min}$ recording. Amplitudes of receptor potentials and the receptor cell input resistance increased during and after the basal cell stimulation. Resting potentials are given to the left of each trace. $B$, Superimposed traces at an expanded time scale of responses immediately preceding and immediately following the recordings shown in $A$ (i.e., at points $a, a^{\prime}, b, b$ ).

they did not reflect spontaneous fluctuations). In the remaining 12 pairs of receptor/basal cells, stimulating the basal cell had no significant effect $(<10 \%$ change) on any of these parameters.

Although receptor cells and basal cells are capable of generating action potentials (Roper, 1983; Bigiani and Roper, 1993; Delay, Mackay-Sim, Taylor, Kinnamon, and Roper, unpublished observations), under the conditions employed in the present experiments (isolated tissue and high $[\mathrm{Ca}]_{o}$ ) we only occasionally observed active responses. This may explain the necessity of using somewhat longer electrical stimulation pulses $(1 \mathrm{sec})$ to mimic trains of action potentials that might occur in vivo. Brief stimulating pulses $(<1 \mathrm{sec})$, although investigated extensively in these experiments (data not shown), do not elicit synaptic or modulatory responses.

An important control was to test whether merely the repetitive electrical depolarization of one cell could elicit nonspecific alterations in the properties of any adjacent cell in the taste bud,
Receptor cell
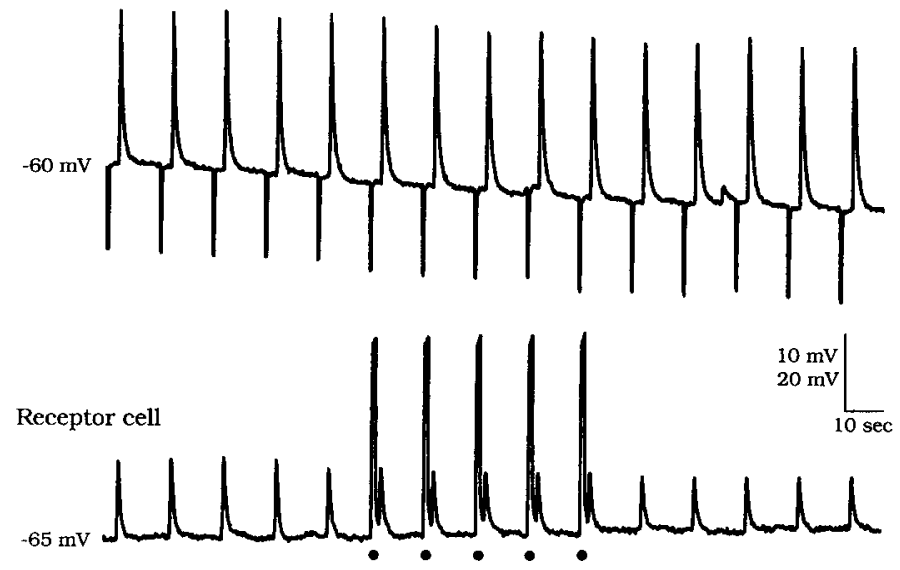

Figure 10. Receptor cells are not affected by repetitive stimulation of other receptor cells. Upper trace, A continuous $3 \mathrm{~min}$ intracellular recording from a taste receptor cell. The microelectrode was inserted into the basal process of the receptor cell. As in Figure 9, focal $\mathrm{KCl}$ stimulation, applied to the taste pore, elicited receptor potentials every 12 sec. $\mathrm{KCl}$ stimuli were alternated with brief hyperpolarizing constant current pulses (not shown) to test the input resistance (downward deflections in trace). Lower trace, Concurrent intracellular recording from an adjacent receptor cell, also impaled in the basal end of the taste bud. Five depolarizing current pulses (๑) were injected halfway through the 3 min recording. The amplitude of receptor potentials and receptor cell input resistance were not changed during and after stimulating the adjacent receptor cell. Resting potentials are given to the left of each trace.

for example, mediated by electrical fields generated in the taste bud or an efflux of $\mathrm{K}^{+}$from depolarized cells into the extracellular space. To test for any such nonselective effects, we used the identical protocol to stimulate pairs of adjacent receptor cells. In all 10 receptor/receptor cell pairs, electrical stimulation did not increase the amplitude of $\mathrm{KCl}$ responses or the input resistance, nor did it hyperpolarize the membrane potential of the paired receptor cell. An example of one such control experiment is shown in Figure 10.

As might be expected, there was a correlation between the amplitude of the $\mathrm{KCl}$ responses and the input resistances of the taste receptor cells. The modulatory effects occurred in only about half of the basal/receptor cell pairs. We plotted changes in the $\mathrm{KCl}$ responses as a function of changes in input resistance for individual experiments (Fig. 11A). Changes in $\mathrm{KCl}$ response and input resistance were normalized by expressing the changes as ratios, that is, values before and after stimulation compared to values immediately preceding stimulation. The ratios for $\mathrm{KCl}$ responses were plotted against the ratios for input resistance 1 min before stimulation (๑) (i.e., the control period) and $1 \mathrm{~min}$ after stimulating a basal cell $(O)$. Thus, the solid circles monitor the normal fluctuations of $\mathrm{KCl}$ responses and input resistance in the absence of any electrical stimulation. Figure $11 \mathrm{~A}$ shows that increases in $\mathrm{KCl}$ responses were correlated with increases in receptor cell input resistance. Furthermore, the proportional changes in $\mathrm{KCl}$ responses and input resistances were about equal; the slope is $\sim 1$. Figure $11 B$ shows that in control experiments where adjacent receptor cells were impaled and stimulated, there were no significant changes in $\mathrm{KCl}$ responses or input resistances (compare Fig. 10).

Immunocytochemical and autoradiographic studies have recently shown that one type of basal taste cell, the Merkel-like 
A Receptor cells: Effect of Basal cell stimulation

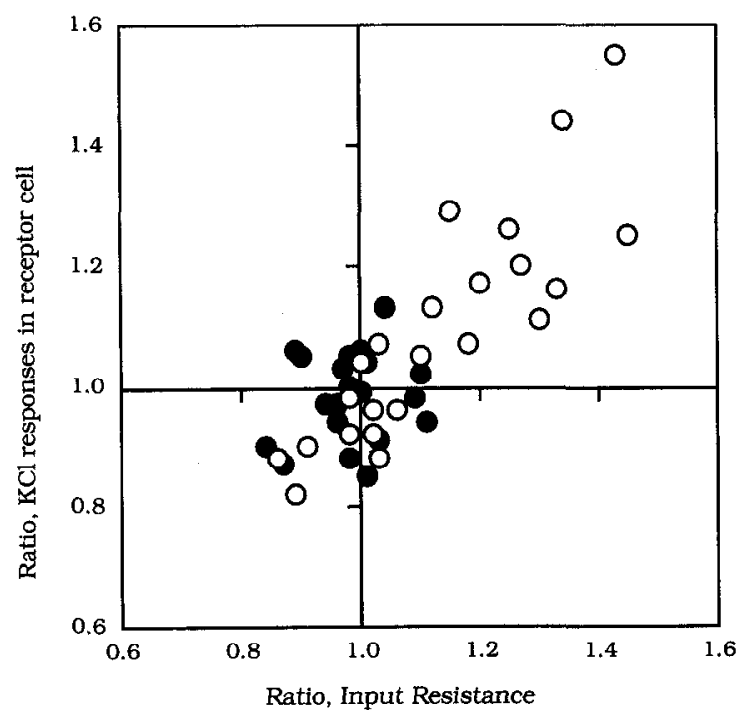

B

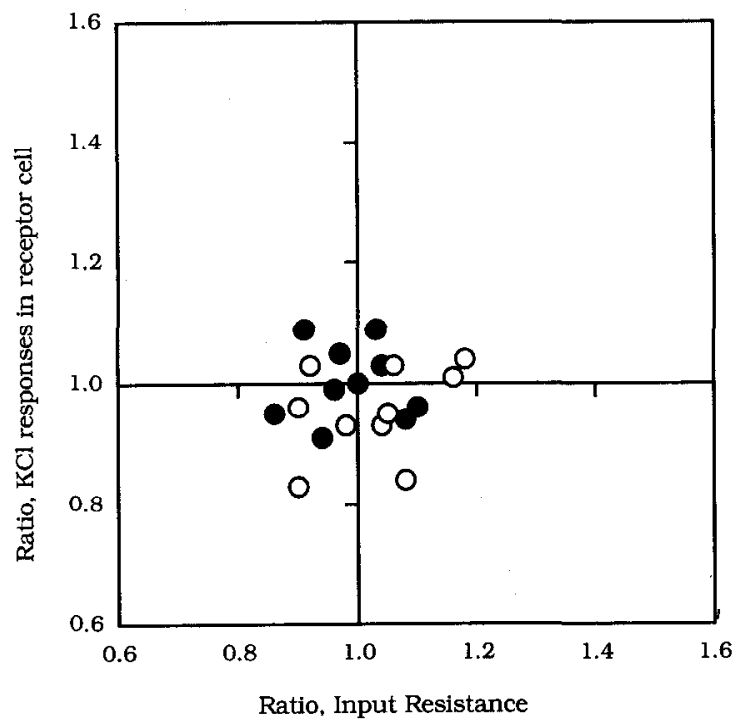

Figure 11. Plots of changes in receptor potentials ( $\mathrm{KCl}$ responses) as a function of receptor cell input resistance caused by repetitive electrical stimulation of basal cells. $A$, For each of 23 basal cell/receptor cell pairs, the basal cell was electrically stimulated with four to six 1 sec depolarizing pulses as in Figure $9 . \mathrm{KCl}$ responses and input resistances in receptor cells were measured at $1 \mathrm{~min}$ before basal cell stimulation $(t$ $=-1$ ), immediately before stimulation $(t=0)$, and $1 \mathrm{~min}$ after the end of stimulation $(t=+1)$. The values of $t=-1$ and $t=+1$ were compared to their values at $t=0$ and expressed as ratios. Thus, a ratio of 1.0 on the abscissa indicates no change in the input resistance over the $1 \mathrm{~min}$ interval. Similarly, a value of 1.0 on the ordinate indicates there were no changes in $\mathrm{KCl}$ responses. The ratios for $\mathrm{KCl}$ responses are plotted as a function of ratios for input resistance for each pair before, $t=-1$ (๑), and after, $t=+1(\mathrm{O})$, stimulation. Electrical stimulation of basal cells caused $>10 \%$ increases in $\mathrm{KCl}$ responses and input resistances in 11 of the 23 paired receptor cells. $B$, Control experiments, stimulating pairs of adjacent receptor cells. For each of 10 receptor cell/receptor cell pairs, similar electrical stimulation of one receptor cell, as in Figure 4, did not cause increases in amplitude and input resistance in the paired receptor cell.
A

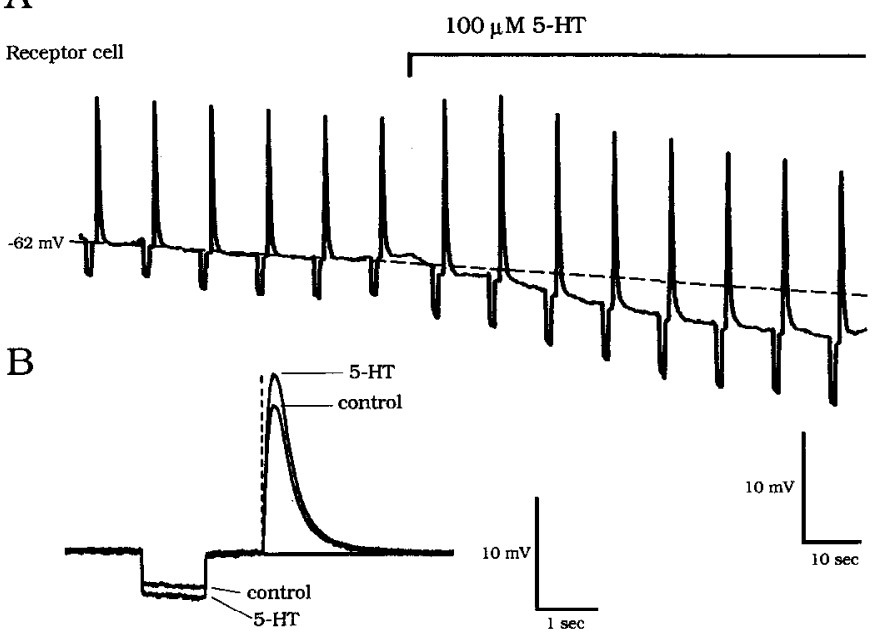

Figure 12. Effects of bath-applied 5-HT on receptor cell function. $A$, A continuous $3 \mathrm{~min}$ recording from a receptor cell. The microelectrode was inserted into the basal process of the receptor cell. Focal $\mathrm{KCl}$ stimulation applied to the tastc pore clicited receptor potentials every 12 sec. $\mathrm{KCl}$ stimuli were alternated with brief hyperpolarizing constant current pulses (not shown) to test the input resistance (downward deflections in trace). Amplitudes of receptor cell responses and receptor cell input resistance were increased during exposure to $100 \mu \mathrm{M}$ 5-HT. Resting potential is given to the left of the trace. $B$, Recordings (superimposed) of $\mathrm{KCl}$ responses and input resistance recorded in the basal process of a receptor cell at expanded time scale before and after trace shown in $A$. Dashed vertical line coincides with onset of receptor potential recorded in the apical end of the taste bud.

basal cell, contains 5-HT (Delay et al., 1993). In the following experiments we investigated the possibility that stimulating basal cells released 5-HT and that this release of 5-HT mediated the modulatory effects on receptor cell function observed above. We tested the ability of bath-applied 5-HT to modulate receptor cell function. Figure 12 shows the effects of bath exposure to $100 \mu \mathrm{M} 5-\mathrm{HT}$ on a receptor cell. The basal process of the receptor cell was impaled with a microelectrode, and $\mathrm{KCl}$ stimuli were applied to the apical tip of the cell. After 2 min of exposure to $5-\mathrm{HT}$, the $\mathrm{KCl}$ responses were increased by $20 \%$, input resistance was increased by $40 \%$, and the membrane potential was hyperpolarized by $4 \mathrm{mV}$. We also tested the effect of $5-\mathrm{HT}$ on basal cells. In contrast to the effect on receptor cells, 5-HT caused an increase in the postsynaptic responses of basal cells (evoked by $\mathrm{KCl}$ stimulation of adjacent receptor cells), but 5-HT did not significantly or consistently change the input resistance of basal cells or produce any consistent hyperpolarization of the resting potential. Figure 13 shows an example with a $30 \%$ increase in postsynaptic responses in a basal cell occurring $2 \mathrm{~min}$ after adding $100 \mu_{\mathrm{M}} 5$-HT to the bath. These effects were consistently observed in each of 14 receptor cells and in each of nine basal cells.

When microelectrodes were inserted into the apical process of taste receptor cells, amplitudes of receptor potentials were $n o t$ affected by exposure to $100 \mu \mathrm{M} 5$-HT $(N=12$ cells). These findings were expected since $\mathrm{KCl}$ produces a large shunt in membrane resistance at the apical tip (compare Fig. 2; Bigiani and Roper, 1991). This apical shunt obscures any amplitude changes that might be recorded at more basal regions (where synapses are situated) due to enhanced electrotonic propagation of the signals throughout the length of the cell. 
A

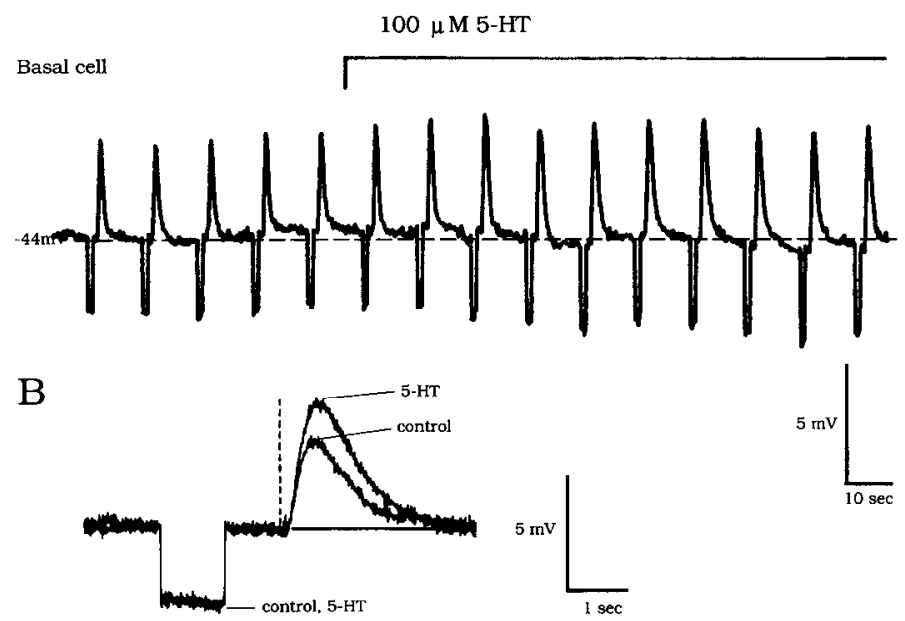

Figure 13. Effects of bath-applied 5-HT on basal cell function. A, A continuous $3 \mathrm{~min}$ recording from a basal cell. Focal $\mathrm{KCl}$ stimulation applied to the taste pore elicited postsynaptic responses in the basal cell, $\sim 4 \mathrm{mV}$, every $12 \mathrm{sec}$. $\mathrm{KCl}$ stimuli were alternated with brief hyperpolarizing constant current pulses (not shown) to test the input resistance (downward deflections, $\sim 3 \mathrm{mV}$, in trace). The amplitude of basal cell responses to chemical stimulation was increased during exposure to 100 $\mu_{\mathrm{M}}$ 5-HT. The basal cell input resistance was not significantly changed. Resting potential is given to the left of the trace. $B$, Recordings (superimposed) of $\mathrm{KCl}$ responses and input resistance at expanded time scale before and after trace shown in $A$. Dashed vertical line coincides with onset of receptor potential recorded in the apical end of the taste bud.

The effects of 5-HT on taste cells are summarized in Figure 14, $A$ (receptor cells) and $B$ (basal cells). As in Figure 11, the ratios for $\mathrm{KCl}$ responses are plotted against the ratios for input resistance. For each experiment, responses were measured $1 \mathrm{~min}$ before 5-HT (๑) and 2 min after adding 5-HT (O). The solid circles give an indication of the normal variability in $\mathrm{KCl}$ responses and input resistances in the absence of any applied drug. These plots allow a direct comparison of the pharmacological effects of 5-HT on receptor cells (Fig. 14A) with the effects of basal cell stimulation on receptor cells (Fig. 11A). In both cases (electrical stimulation and 5-HT application), increases in $\mathrm{KCl}$ responses were correlated with increases in input resistance. However, bath-applied 5-HT consistently affected all receptor cells, whereas stimulating basal cells only elicited responses in about half of the receptor cells.

We also plotted the changes in $\mathrm{KCl}$ responses and input resistances as a function of time after adding 5-HT to the bath for receptor cells (Fig. 15A) and basal cells (Fig. 15B). In Figure $15 \mathrm{C}$, these parameters are plotted for the subpopulation of receptor cells (11 of 23 pairs) in which stimulating basal cells elicited responses (Fig. 11A). The rationale for selecting this subset of data is that it allows a comparison of the effects of stimulating basal cells (Fig. $15 C$ ) with the effects of bath-applied 5-HT (Fig. 15A). This comparison shows that the magnitude and time course of the effects on both $\mathrm{KCl}$ responses and input resistance evoked by stimulating basal cells or by bath applying 5-HT are very similar.

\section{Discussion}

A network of chemical synaptic interactions has been morphologically identified in Necturus taste buds (Delay and Roper, 1988). Most of the cells in each taste bud are receptor cells, but
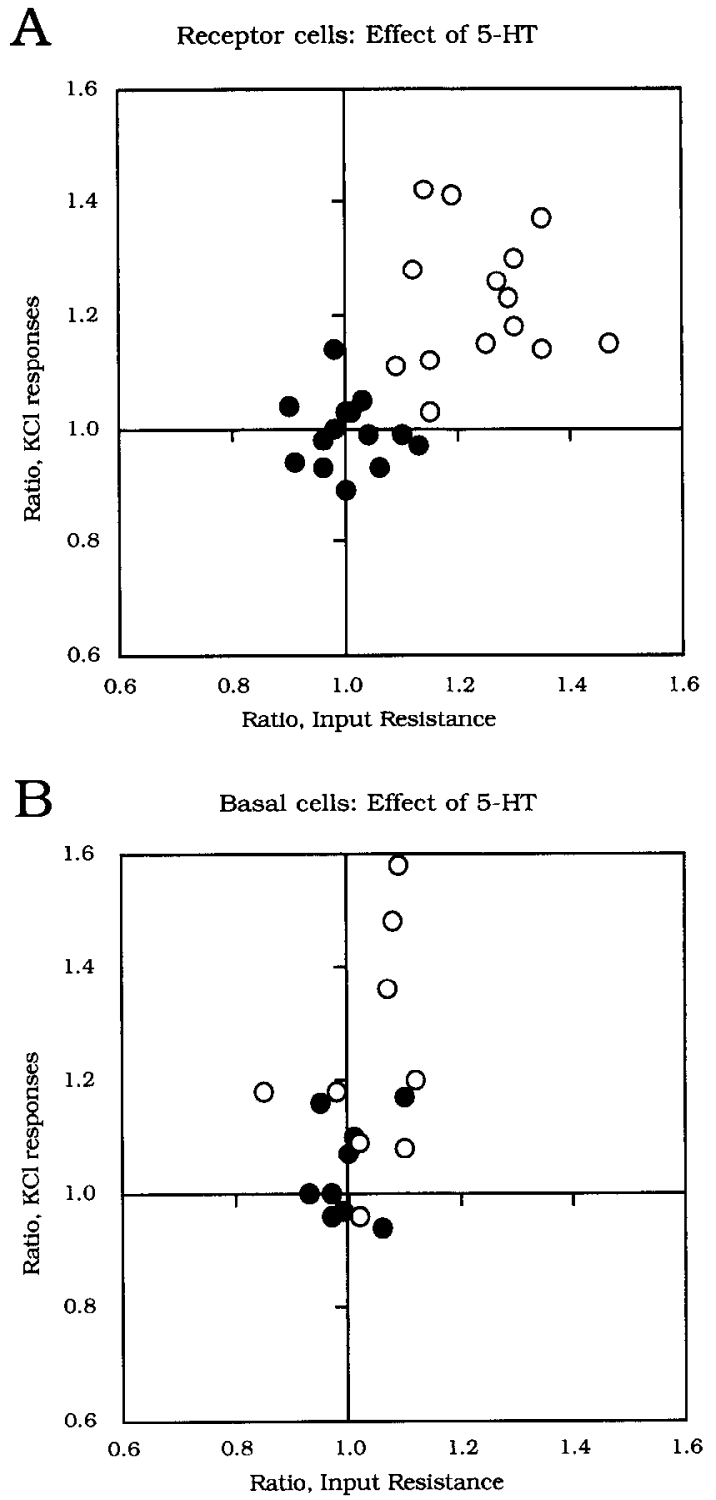

Figure 14. Plots of changes in $\mathrm{KCl}$ responses as a function of input resistance for receptor cells $(A)$ and for basal cells $(B)$ produced by 100 $\mu \mathrm{M}$ 5-HT. $A$, Fourteen receptor cells were impaled in their basal processes and exposed to $100 \mu \mathrm{M}$ 5- $\mathrm{HT}$. $\mathrm{KCl}$ responses and input resistances were measured at $1 \mathrm{~min}$ before, $t=-1$, immediately preceding, $t=0$, and 2 min after adding 5-HT, $t=2$. The values measured $t=-1$ and $t=2$ were compared to their values at $t=0$, and expressed as ratios. The ratios for $\mathrm{KCl}$ responses are plotted as a function of the ratios for input resistance before, $t=-1(\bullet)$, and after, $t=2(\mathrm{O}), 5-\mathrm{HT}$. Exposure to $100 \mu \mathrm{M} 5-\mathrm{HT}$ caused increases in both the $\mathrm{KCl}$ responses and input resistances of all 14 receptor cells. $B$, For each of nine basal cells, exposure to $100 \mu \mathrm{M}$-HT caused increases in postsynaptic potentials (elicited by $\mathrm{KCl}$ stimulation) without significant increases in input resistance. Analysis and graphical format are the same as in $A$.

only a minority of the synapses are found between receptor cells and afferent nerve fibers. More than half of the synapses in the taste bud involve a type of basal cell, the "Merkel-like" basal cell (Delay and Roper, 1988; Delay et al., 1993). These basal cells form synapses both with the afferent nerve and with receptor cells. Previous studies (Reutter, 1978) have suggested that basal cells may function as some sort of interneuron within the taste bud, presumably mediating some form of information processing in the peripheral taste organ. In some cases synaptic 
A

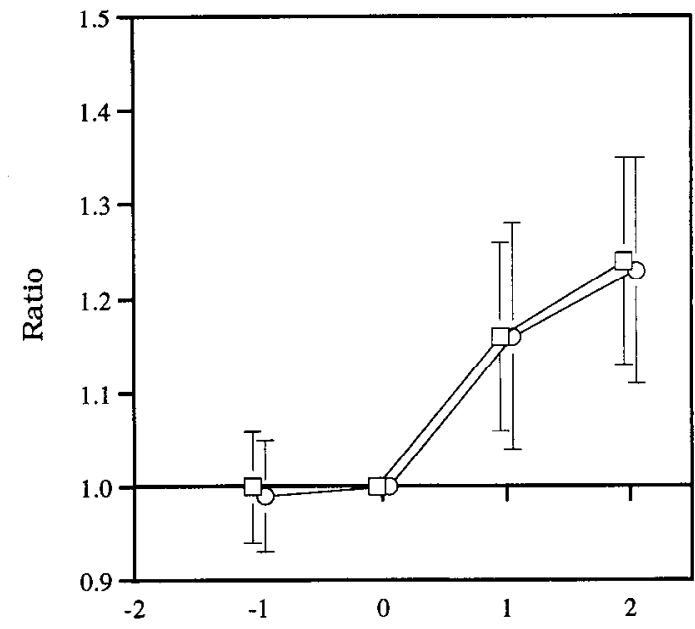

B

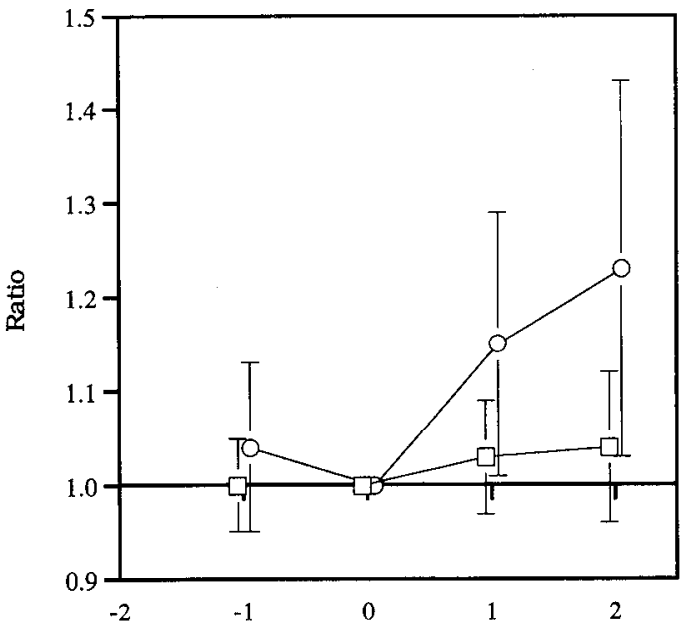

C

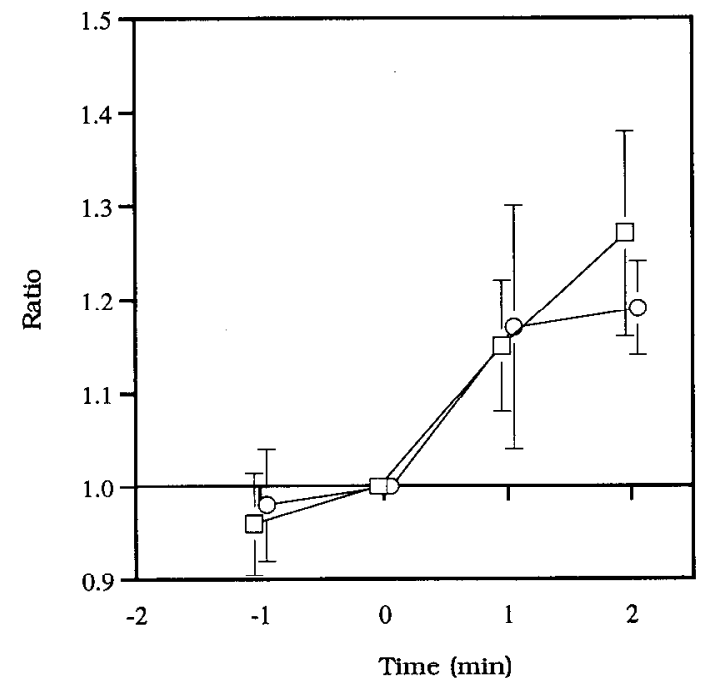

Receptor cells: Effect of 5-HT

$\square$ Input Resistance

KCl Response

Basal cells:

Effect of 5-HT

$\square-$ Input Resistance

$\longrightarrow \mathrm{KCl}$ Response
Receptor cells:

Effect of electical stimulation of basal cells

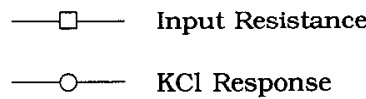

Figure 15. Time course and magnitude of the effects of bath-applied 100 $\mu \mathrm{M} 5-\mathrm{HT}$ on $\mathrm{KCl}$ responses and input resistances of receptor cells $(A)$ and basal cells $(B)$. $A$, Receptors cells were impaled in their basal processes. $\mathrm{KCl}$ responses and input resistances of the receptor cells were measured $1 \mathrm{~min}$ before, immediately preceding, $1 \mathrm{~min}$ after, and 2 min after adding 5-IIT. These values were normalized to the measurement just preceding exposure, and expressed as ratios as in Figure 14. The means \pm SD of these ratios are plotted for both variables at each time. $B$, Changes in these same parameters are plotted for basal cells exposed to 100 $\mu \mathrm{M}$ 5-HT. $C$. Electrical stimulation of basal cells resembles effects of exogenous 5-HT. Changes in $\mathrm{KCl}$ responses and input resistances are plotted for the receptor cells in which basal cell stimulation elicited measurable changes ( 11 of 23 pairs; see Fig. $11 \mathrm{~A}$ and text). profiles between receptor cells and basal cells suggest the presence of bidirectional synapses (Delay and Roper, 1988). Such synapses are thought to be involved in synaptic feedback between neurons in other systems (Anderson, 1985; Horvath et al., 1989). The first part of the present study is concerned with the electrophysiological properties of the synaptic output from receptor cells onto basal cells. This output may represent one direction of a bidirectional communication between these two cell types.

\section{Postsynaptic responses in basal cells}

In recordings from the basal region of Necturus taste buds we have previously shown that presynaptic responses in receptor cells can be differentiated from postsynaptic responses in basal cells by the longer latency of the latter to chemical stimulation of the entire receptor cell population at the apical pore (Ewald and Roper, 1992). This discrimination between pre- and postsynaptic responses in the basal region was accomplished by 
comparing receptor potentials in the apical end with responses in the basal region in sequential recordings with a single microelectrode. In the present experiments we have used two microelectrodes to record simultaneously from pairs of cells during chemical stimulation. With simultaneous recordings from pairs consisting of a receptor cell (recorded in the apical end) and a basal cell or a receptor cell (recorded in the basal region), we have confirmed the delayed onset of basal cell responses. Our results suggest that synaptic connections between receptor cells and basal cells have characteristics that are consistent with known properties of chemical synapses.

First, transmitter release is elicited when the presynaptic potential reaches a threshold membrane voltage sufficient to activate Ca channels. Kinnamon and Roper (1988a) showed that in isolated Necturus taste receptor cells, voltage-dependent $\mathrm{Ca}$ currents had a threshold of $\sim-10 \mathrm{mV}$. This may be more depolarized than in intact tissue or may overestimate the threshold depolarization needed to trigger synaptic transmitter release. Synapses in Necturus taste cells tend to be situated on the basal processes of receptor cells (Delay and Roper, 1988), at an appreciable distance $(50-100 \mu \mathrm{m})$ from the taste pore. Although we have shown here that the threshold for evoking basal cell responses was when the $\mathrm{KCl}$ potential depolarized receptor cells to $\sim-20 \mathrm{mV}$ (Fig. 5), this referred to the apical depolarization, not the depolarization at basal (synaptic) sites. Furthermore, $\mathrm{CaCl}_{2}$ responses triggered hasal cell responses at much smaller apical receptor potentials (compare Fig. 3). This is consistent with the more efficient electrotonic spread of $\mathrm{CaCl}_{2}$ potentials throughout taste receptor cells due to the increase in the membrane input resistance of the receptor cell (and a concomitant increase in electrotonic length constant) during $\mathrm{CaCl}_{2}$ responses.

Second, once the presynaptic threshold has been exceeded, the postsynaptic potential is a function of the level of presynaptic depolarization as well as the duration that this suprathreshold depolarization is maintained. This voltage and time dependence of postsynaptic responses in basal cells is under conditions in which the entire receptor cell population is stimulated by $\mathrm{KCl}$ or $\mathrm{CaCl}_{2}$. To gain information about the properties of individual synapses, we impaled pairs of cells that were synaptically coupled and directly stimulated the presynaptic clement (receptor cell). The properties of these responses were consistent with their being mediated by a chemical synapse. In particular, the responses were evoked only by depolarization. No other events in basal cells were observed with electrical stimulation of receptor cells that might account for the postsynaptic responses in basal cells during chemical stimulation. Thus, we conclude that small depolarizing responses from numerous receptor cells onto each basal cell account for the observed postsynaptic response when all the receptor cells are depolarized by the chemical stimulus.

An alternative interpretation to the existence of discrete synaptic connections between receptor and basal cells, that might, in part, be consistent with our findings is that depolarized receptor cells release $\mathrm{K}^{+}$into the limited extracellular spaces within the taste bud. Similar mechanisms have been reported in the retina (Karwoski et al., 1989) and in olfactory cpithclium (Khayari et al., 1991). Our findings with $\mathrm{K}$-sensitive microelectrodes (Ewald and Roper, 1992) indicate that $\mathrm{K}^{+}$release into the taste bud does, indeed, occur to some extent when receptor cells are depolarized. If the extracellular spaces are sufficiently restricted that $\left[\mathrm{K}^{+}\right]_{o}$ rises appreciably, this could produce a weak, slow, and prolonged depolarization of basal cells such as we observed.
We do not believe this is a complete or even likely explanation, though such changes in $\left[\mathrm{K}^{+}\right]_{0}$ may contribute to the postsynaptic responses. First, it would be difficult to explain the rapid onset of basal cell responses after direct electrical depolarization of an individual receptor cell (e.g., Fig. 6), based solely on changes in $\left[\mathrm{K}^{+}\right]_{\circ}$. Second, morphological evidence for chemical synapses between receptor and basal cells has been reported (Reutter, 1978; Delay and Roper, 1988).

We attempted to determine the ratio of the entire synaptic input onto a given basal cell to the synaptic input from a single receptor cell. We compared the amplitude of the postsynaptic potential produced by chemical stimulation of the entire receptor cell population with the maximum amplitude of the concurrently measured response during depolarization of a single receptor cell. this ratio, $\sim 8: 1$, is one measure of the synaptic convergence from receptor cells onto basal cells. This ratio is about the samc as the ratio of the population sizes of the receptor cells to the Merkel-like basal cells $(\sim 12: 1)$ (Delay and Roper, 1988; Kim and Roper, unpublished observations). One possible interpretation of the similarity of these ratios is that the synaptic output from receptor cells onto basal cells is complete but not redundant. That is, several receptor cells synapse with one basal cell, but individual receptor cells do not provide divergent synaptic output onto two or more basal cells.

Morphological evidence suggests that there are numerous synapses between receptor and basal cells (Delay and Roper, 1988). Thus, basal cells could function as interneurons or serve a neuromodulator function within the taste bud. However, the amplitude of the postsynaptic responses in basal cells is quite small (only $\sim 3 \mathrm{mV}$ when all the presynaptic receptor cells were depolarized to $0 \mathrm{mV}$ ). Thus, it seems unlikely that basal cells function as conventional interneurons between (in series with) receptor cells and afferent nerve fibers. Another possible role for the postsynaptic response in basal cells, as part of a feedback circuit, is suggested by the presence of bidirectional synapses, and is described below.

\section{Modulation of receptor cell function by basal cells}

Synapses in the reverse direction, from basal cells onto receptor cells, are also found in Necturus taste buds (Delay and Roper, 1988). These "reverse" synapses were often part of bidirectional synapses. Their existence suggests that one possible role for the postsynaptic response in basal cells, discussed above, is as part of a feedback circuit on receptor cell function, such as those described in other systems (Anderson, 1985; Horvath et al., 1989). Thus, we have also tested for synaptic output from basal cells onto receptor cells. Although single electrical stimuli applied to basal cells did not evoke postsynaptic responses in receptor cells, multiple electrical stimuli to basal cells did produce long-term modulatory effects in about half of the receptor cells. The modulatory effects observed in the receptor cells consisted of an increase in the amplitude of responses to chemical stimulation, an increase in input resistance, and a hyperpolarization of the resting potential.

When basal cell stimulation produced changes in the receptor cell propertics, the changes in $\mathrm{KCl}$ responses and input resistances were correlated. This correlation between increases in receptor potentials and input resistances suggests that the mechanism for the increased chemosensitivity is due to enhanced electrotonic condüction of apical receptor potentials along the length of the receptor cells. The changes in resting membrane conductances that underlie the increase in input resistance are 
unknown. However, the increase in input resistance combined with a hyperpolarization indicates a net decrease in inward current, at or near the resting membrane potential, in the receptor cells.

The effects produced by repetitive stimulation of basal cells were observed in about half of the pairs of receptor/basal cells. In our experiments, pairs of cells were impaled at random and stable recordings were not always reliably obtained from adjacent cells. There was no way to predetermine which cells were synaptically coupled and thus to increase the incidence of basalreceptor cell interactions. Consequently, we were struck by the relatively high percentage of cell pairs in which basal cell stimulation modulated receptor cell responses. One interpretation of this finding is that an effective concentration of the neuromodulator released by stimulated basal cells diffuses sufficiently to affect about half of the receptor cells in the taste bud. The anatomy of the taste bud supports this interpretation: basal processes of receptor cells converge at the base of the taste bud to form a core around which the basal cells are peripherally located (Delay et al., 1993; Kim et al., 1993). We estimate that the effective concentration of the neuromodulator would need to extend only about $10-20 \mu \mathrm{m}$ beyond the basal cell in order to affect half of the receptor cells. Thus, our finding that the effect of stimulation of a single basal cell is widespread, but not complete, is consistent with the anatomy of the taste bud and a reasonable diffusion distance for the neuromodulator. Of course, unknown properties for the neuromodulator (e.g., its rate of release, receptor type, and rate of reuptake or degradation) will combine to determine its actual effective concentration within the taste bud. These properties all depend on the identity of the neuromodulator. As discussed below, our data suggest the identification of this neuromodulator as 5-HT.

Immunocytochemical and autoradiographic studies have recently shown that one type of basal taste cell, the Merkel-like basal cell, contains 5-HT (Welton and Roper, 1992; Welton et al., 1992; Delay et al., 1993). Furthermore, 5-HT is released when Merkel-like basal cells are depolarized (Welton and Roper, 1992). Our data show that exogenous 5-HT (100 $\mu \mathbf{M})$ mimics the effects of repetitively stimulating basal cells. Thus, chemosensory receptor potentials were increased, the input resistance of receptor cells was increased, and the membrane potential of receptor cells was hyperpolarized. Similar effects of 5-HT on the passive membrane properties have been reported on insect olfactory neurons (e.g., Kloppenburg and Hildebrand, 1992; Mercer et al., 1992). Furthermore, concentrations of 5-HT (50 $\mu \mathrm{M}$ to $1 \mathrm{mM}$ ) have been reported to alter signaling in other sensory systems in vertebrates (Esakov et al., 1983; Mroz and Sewell, 1989; Drujan et al., 1990). We do not know if other biogenic amines or peptides that have also been identified in taste buds (e.g., see Table 3 in Welton et al., 1992) may have similar effects. Our model for the modulatory effects of basal cell stimulation, mediated by release of $5-\mathrm{HT}$, is diagrammed schematically in Figure 16.

Postsynaptic responses recorded in basal cells were also increased by exposure to 5-HT, but without an increase in the input resistance of basal cells. This effect is consistent with the hypothesis that 5-HT acts on the presynaptic (receptor) cells without any direct effect on the basal cell. That is, 5-HT enhances the amplitude of the presynaptic signals (receptor potentials) and this, in turn, increases postsynaptic responses in basal cells. In principle, this should represent positive feedback. Receptor potentials would elicit 5-HT release from (postsyn-

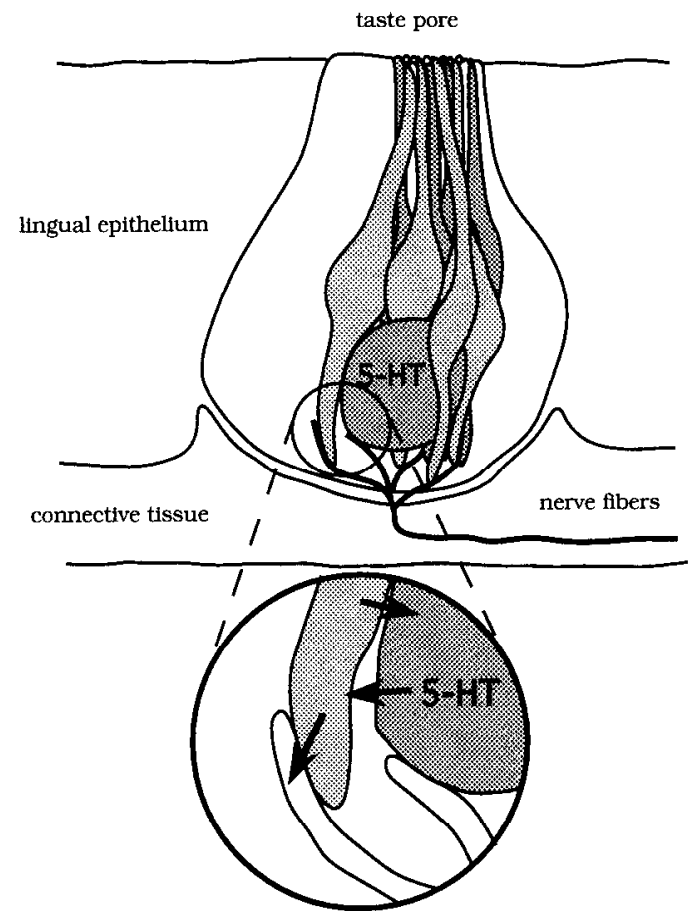

Figure 16. Schematic diagram showing the proposed synaptic relations in Necturus taste buds. Synaptic input from a group of receptor cells converges onto a basal cell. The basal cell is hypothesized to contain and release 5-HT when it is stimulated. The basal region of the taste bud, enlarged below, shows synaptic output from a receptor cell onto a basal cell (upper arrow), 5-HT released from a basal cell that modulates the receptor cell (middle arrow), and synaptic output from the receptor cell onto the affcrent ncrve (lower arrow).

aptic) basal cells. This in turn would increase the (presynaptic) receptor potential further, enhance postsynaptic responses, and thus promote further release of 5-HT. However, despite this positive feedback, responses would ultimately be limited by several factors including rates of diffusion and reuptake of 5-HT, and the maximum increase in receptor cell membrane resistance that could be produced by $5-\mathrm{HT}$.

$5-\mathrm{HT}$, in addition to its effects on the passive membrane properties of receptor cells, shown here, and hence on the electrotonic propagation of chemosensory receptor potentials from apical to basal synaptic regions in the receptor cell, also exerts powerful effects on voltage-dependent currents, especially $\mathrm{Ca}$ currents $\left(I_{\mathrm{Ca}}\right)$. For example, Delay et al. (1992) have shown that 5-HT increases $I_{\mathrm{Ca}}$ in some taste receptor cells and decreases $I_{\mathrm{Ca}}$ in other taste receptor cells. We did not observe a similar division of receptor cells based on the effects of 5-HT on passive membrane properties in the present experiments. $I_{\mathrm{Ca}}$ is important in neurotransmitter release. Thus, we hypothesize that in some receptor cells the stimulatory effect of 5-HT on $I_{\mathrm{Ca}}$ reported by Delay et al. (1992) will complement the effects of 5-HT on the passive properties, reported here. Both actions will enhance chemosensory responses in the taste bud. However, in other receptor cells, the inhibitory effect of 5-HT on $I_{\mathrm{Ca}}$ will oppose the action of 5-HT that we observed. The consequence of this for the overall function of taste buds during chemostimulation is that 5-HT seems to have multiple effects on receptor cells and may exert a complex modulation of signals within the peripheral taste organ. 


\section{References}

Anderson PAV (1985) Physiology of a bidirectional, excitatory, chemical synapse. J Neurophysiol 53:821-835.

Bigiani AR, Roper SD (1991) Mediation of responses to calcium in taste cells by modulation of a potassium conductance. Science 252 : 126-128.

Bigiani AR, Roper SD (1993) Identification of electrophysiologically distinct cell subpopulations in Necturus taste buds. J Gen Physiol 102: 143-170.

Birrell GJ, McQueen DS, Iggo A, Grubb BD (1990) The effects of $5-\mathrm{HT}$ on articular sensory receptors in normal and arthritic rats. $\mathrm{Br}$ J Pharmacol 101:715-721.

Delay RJ, Roper SD (1988) Ultrastructure of taste cells and synapses in the mudpuppy Necturus maculosus. J Comp Neurol 277:268-280.

Delay RJ, Kinnamon SC, Roper SD (1992) Membrane properties and transmitter sensitivity of Merkel-like basal cells and taste cells in Necturus taste buds. Chem Senses 17:610.

Delay RJ, Taylor R, Roper SD (1993) Merkel-like basal cells in Necturus taste buds contain serotonin. J Comp Neurol 335:606-613.

Drujan BD, Salas R, Laufer M, Urbina M (1990) Retinal neurotransmitter interaction as reflected in horizontal cell spatial behaviour. $\mathbf{J}$ Neural Transm [Suppl] 29:153-162.

el Manira A, Rossi-Durand C, Clarac F (1991) Serotonin and proctolin modulate the response of a stretch receptor in crayfish. Brain Res 541:793-795.

Esakov AI, Golubtsev KV, Solovieva NA (1983) The significance of serotonin in the activity of the taste receptor apparatus of the frog Rana temporaria. Zh Evol Biokhim Fiziol 19:62-67.

Ewald DA, Roper SD (1992) Intercellular signaling in Necturus taste buds: chemical excitation of receptor cells elicits responses in basal cells. J Neurophysiol 67:1316-1324.

Fujimoto S, Ueda H, Kagawa H (1987) Immunocytochemistry on the localization of 5-hydroxytryptamine in monkey and rabbit taste buds. Acta Anat 128:80-83.

Horvath S, Palkovits M, Gorcs T, Arimura A (1989) Electronmicroscopic immunocytochemical evidence for the existence of bidirectional synaptic connections between growth-releasing hormonecontaining and somatostatin-containing neurons in the hypothalamus of the rat. Brain Res 481:8-15.

Karwoski CJ, Lu HK, Newman EA (1989) Spatial buffering of lightevoked potassium increases by retinal Muller (glial) cells. Science 244: 578-580.

Khayari A, Math F, Trotier D (1991) Odorant-evoked potassium changes in the frog olfactory epithelium. Brain Res 539:1-5.

Kim D-J, Delay RJ, Roper SD (1993) Merkel-like basal cells in amphibian taste buds are homologous with type III cells in mammalian taste buds. Soc Neurosci Abstr 19:1428.

Kinnamon SC (1987) Organization and innervation of taste buds. In: Neurobiology of taste and smell. New York: Wiley.

Kinnamon SC (1988) Taste transduction: a diversity of mechanisms. Trends Neurosci 11:491-496.

Kinnamon SC, Roper SD (1987) Passive and active membrane properties of mudpuppy taste receptor cells. J Physiol (Lond) 383:601614.

Kinnamon SC, Roper SD (1988a) Membrane properties of isolated mudpuppy taste cells. J Gen Physiol 91:351-371.

Kinnamon SC, Roper SD (1988b) Evidence for a role of voltagesensitive apical $\mathrm{K}^{+}$channels in sour and salt taste transduction. Chem Senses 13:115-121.

Kinnamon SC, Dionne VE, Beam KG (1988) Apical localization of $\mathrm{K}^{+}$channels in taste cells provides the basis for sour taste transduction. Proc Natl Acad Sci USA 85:7023-7027.

Kloppenburg P, Hildebrand JG (1992) Modulatory effects of 5-HT on interneurons in the antennal lobe of the sphinx moth Manduca sexta. Soc Ncurosci Abstr 18:303.

Lang E, Novak A, Reeh PW, Handwerker HO (1990) Chemosensitivity of fine afferents from rat skin in vitro. J Neurophysiol 63:887901.

Mercer AR, Hayashi JH, Hildebrand JG (1992) Modulatory effects of 5-HT on voltage-gated currents in cultured insect olfactory neurons. Soc Neurosci Abstr 18:303.

Mitchell CK, Redburn DA (1985) Analysis of pre- and postsynaptic factors of the serotonin system in rabbit retina. J Cell Biol 100:6473.

MrozEA, Sewell WF (1989) Pharmacological alterations of the activity of afferent fibers innervating hair cells. Hear Res 38:141-162.

Nada O, Hirata K (1975) The occurrence of the cell type containing a specific monoamine in the taste bud of the rabbit's foliate papilla. Histochemistry 43:237-240.

Osborne NN (1982) Uptake, localization, and release of serotonin in the chick retina. J Physiol (Lond) 331:469.

Osborne NN, Nesselhut T, Nicholas DA, Patel S, Cuello AC (1982) Serotonin-containing neurons in vertebrate retinas. J Neurochem 39 : $1519-1528$.

Pasztor VM (1989) Modulation of sensitivity in invertebrate sensory receptors. Sem in Neurosci 1:5-14.

Pasztor VM, Bush BM (1987) Peripheral modulation of mechanosensitivity in primary afferent neurons. Nature 326:793-795.

Reutter K (1978) Taste organ in the bullhead (Teleostei). Adv Anat Embryol Cell Biol 55:1-98.

Reutter K, Witt M (1993) Morphology of vertebrate taste organs and their nerve supply. In: Mechanisms of taste transduction, Chap 2 (Simon SA, Roper SD, eds), in press. Boca Raton: CRC.

Roper SD (1983) Regenerative impulses in taste cells. Science 220: 1311-1312.

Roper SD (1989) The cell biology of vertebrate taste receptors. Annu Rev Neurosci 12:329-353.

Roper SD (1992) The microphysiology of peripheral taste organs. J Neurosci 12:1127-1134

Roper SD (1993) Synaptic interactions in taste buds. In: Mechanisms of taste transduction, Chap 11 (Simon SA, Roper SD, eds). Boca Raton: CRC.

Roper SD, Ewald DA (1992) Peripheral events in taste transduction. In: Sensory transduction (Roper SD, Corey DP, eds), pp 281-289. New York: Rockefeller UP.

Roper SD, McBride DW (1989) Distribution of ion channels on taste cells and its relationship to chemosensory transduction. J Membr Biol 109:29-39.

Sata O, Sato T (1989) Dye-coupling among cells in taste disk of frog. Chem Senses 14:316.

Siegelbaum SA, Camardo JS, Kandel ER (1982) Serotonin and cyclic AMP close single $\mathrm{K}^{+}$channels in Aplysia sensory neurons. Nature 299:413-417.

Solovieva NA, Krokhina EM, Esakov AI (1978) Possible nature of biogenic amine in the dumb-bell shape cells of the frog taste bud. Byull Eksp Biol Med 86:596-598.

Taiwo YO, Levine JD (1992) Serotonin is a directly-acting hyperalgesic agent in the rat. Neuroscience 48:485-490.

Teeter JH (1985) Dye-coupling in catfish taste buds. In: Proceedings of the 19th Japanese symposium on taste and smell (Kimura S, Miyoshi A, Shimida I, eds), pp 29-33. Hozumicho, Gifu: Asahi University.

Thier P, Wassle H (1984) Indoleamine-mediated reciprocal modulation of on-centre and off-centre ganglion cell activity in the retina of the cat. J Physiol (Lond) 351:613-630.

Todorovic S, Anderson EG (1992) Serotonin preferentially hyperpolarizes capsaicin-sensitive C-type sensory neurons by activating 5-HT1A receptors. Brain Res 585:212-218.

Welton J, Roper SD (1992) In vitro uptake of ${ }^{3} \mathrm{H}$ serotonin in taste buds of the mudpuppy. ACS Abstr 14:194.

Welton J, Taylor R, Porter AJ, Roper SD (1992) Immunocytochemical survey of putative neurotransmitters in taste buds from Necturus maculosus. J Comp Neurol 324:509-521.

Yang J, Roper SD (1987) Dye-coupling in taste buds in the mudpuppy, Necturus maculosus. J Neurosci 7:3561-3565.

Zhu B, Gabriel R, Straznicky C (1992) Serotonin synthesis and accumulation by neurons of the anuran retina. Vis Neurosci 9:377-388. 